\title{
Recent Advances in Covalent Organic Frameworks for Heavy Metal Removal Applications
}

\author{
Maria-Anna Gatou ${ }^{1}$, Panagiota Bika ${ }^{2}$ (D), Thomas Stergiopoulos ${ }^{2,3}$, Panagiotis Dallas ${ }^{2, *(D)}$ \\ and Evangelia A. Pavlatou 1,*
}

1 Laboratory of General Chemistry, School of Chemical Engineering, National Technical University of Athens, Zografou Campus, 9, Iroon Polytechniou Str., Zografou, 15780 Athens, Greece; mgatou2@mail.ntua.gr

2 Institute of Nanoscience and Nanotechnology, National Centre for Scientific Research "Demokritos", 15341 Athens, Greece; p.bika@inn.demokritos.gr (P.B.); t.stergiopoulos@inn.demokritos.gr (T.S.)

3 Laboratory of Physical Chemistry, Department of Chemistry, Aristotle University of Thessaloniki, 54124 Thessaloniki, Greece

* Correspondence: p.dallas@inn.demokritos.gr (P.D.); pavlatou@chemeng.ntua.gr (E.A.P.); Tel.: +30-210-650-3311 (P.D.); +30-210-772-3110 (E.A.P.)

check for updates

Citation: Gatou, M.-A.; Bika, P.; Stergiopoulos, T.; Dallas, P.; Pavlatou, E.A. Recent Advances in Covalent Organic Frameworks for Heavy Metal Removal Applications. Energies 2021, 14, 3197. https://doi.org/ $10.3390 /$ en14113197

Academic Editor: Giorgio Vilardi

Received: 30 April 2021

Accepted: 26 May 2021

Published: 30 May 2021

Publisher's Note: MDPI stays neutral with regard to jurisdictional claims in published maps and institutional affiliations.

Copyright: (c) 2021 by the authors. Licensee MDPI, Basel, Switzerland. This article is an open access article distributed under the terms and conditions of the Creative Commons Attribution (CC BY) license (https:// creativecommons.org/licenses/by/ $4.0 /)$.

\begin{abstract}
Covalent organic frameworks comprise a unique class of functional materials that has recently emerged as a versatile tool for energy-related, photocatalytic, environmental, and electrochromic device applications. A plethora of structures can be designed and implemented through a careful selection of ligands and functional units. On the other hand, porous materials for heavy metal absorption are constantly on the forefront of materials science due to the significant health issues that arise from the release of the latter to aquatic environments. In this critical review, we provide insights on the correlation between the structure of functional covalent organic frameworks and their heavy metal absorption. The elements we selected were $\mathrm{Pb}, \mathrm{Hg}, \mathrm{Cr}, \mathrm{Cd}$, and $\mathrm{As}$ metal ions, as well as radioactive elements, and we focused on their removal with functional networks. Finally, we outline their advantages and disadvantages compared to other competitive systems such as zeolites and metal organic frameworks (MOFs), we analyze the potential drawbacks for industrial scale applications, and we provide our outlook on the future of this emerging field.
\end{abstract}

Keywords: covalent organic frameworks; heavy metals; environmental remediation; wastewater treatment; adsorption

\section{Introduction}

The rapid increase in human consumption and tremendous growth of human population, industrial production, and urbanization during the last decades has led to a high concern regarding water pollution worldwide [1,2].

Wastewater containing high concentrations of heavy metal ions (e.g., $\mathrm{Hg}^{2+}, \mathrm{Pb}^{2+}, \mathrm{Cd}^{2+}$, $\mathrm{Cr}^{6+}$, etc.) deriving from industries, such as mining, metal smelting, electroplating, battery manufacturing, and refineries, are directly or indirectly discharged into the environment [3]. This results in excessive heavy metal loads in water bodies that can reach hundreds of milligrams per liter, by far exceeding the acceptable threshold set at $5 \mathrm{mg} / \mathrm{L}$ for the human body [4-6].

Heavy metal ions, contrary to organic compounds, cannot be reduced or alleviated through physicochemical or biological treatment in nature [7]. Therefore, they are not biodegradable, in this way reducing the quality of water, and they are easily accumulated in aquatic living organisms, imposing a severe threat through the food chain to other species and humans $[1,7,8]$.

Certain heavy metals can interact instantly with proteins and enzymes inside the human body, resulting in an inactivation and accumulation in essential organs. This disruption leads to various diseases and disorders, such as tremors, renal lesions, or even cancer $[1,9]$. 
With respect to the above, it has always been an urgent task for researchers to find an effective method to remove heavy metal ions from wastewater. A variety of techniques are currently being utilized, in order to separate and remove heavy metal ions from several types of wastewater, including solvent extraction [10], chemical precipitation [11], adsorption [12,13], membrane filtration [14,15], photodegradation [8,16], and electrochemical methods [8]. For this purpose, the following functional materials have been used as sorbents and catalysts: activated carbon [17], bio-sorbents [7], modified resins [7], agricultural waste materials [7,18], zeolites [7], magnetic nanomaterials [19], polymer-based nanocomposites [7,20], layered double hydroxides [7,21], metal organic frameworks (MOFs) [22], graphene oxide, and carbon nanotubes [23]. However, these materials are associated with various limitations and drawbacks, such as low adsorption capacity, slow adsorption kinetics, small number of reactive sites, low physical and chemical stability, relatively complicated preparation, and poor reusability $[7,8,24]$.

Covalent organic frameworks (COFs) are crystalline materials of long-range ordered two-dimensional or three-dimensional network structures. They are synthesized through thermodynamically controlled, reversible polymerization of light elements (i.e., $\mathrm{C}, \mathrm{H}, \mathrm{O}$, $\mathrm{N}$, and $\mathrm{B}$ ) via robust covalent bonds between monomeric building blocks $[7,25,26]$. The reversible synthetic reactions ensure the formation of highly ordered frameworks with self-healing ability $[27,28]$. COFs consist of distinct rigid monomers with symmetrical reactive groups at their edges in specific geometries. Different geometry matches of these building monomers or the selection of different kinds of monomers, that are denoted as $\mathrm{Cn}$ according to the number (n) of their symmetrical reactive groups, can alter the structure of COFs, leading to various polygon skeletons, such as hexagonal, tetragonal, trigonal, rhombohedral, and dual-pore kagome [8,27-29]. The variant dimensions of the building units result in either two-dimensional (2D) or three-dimensional (3D) COFs [27]. In the case of 2D covalent organic frameworks, the extended 2D atomic layers are composed by the periodic organic units through covalent bonds and are stacked by $\pi-\pi$ interactions, leading to crystallized layered structures, characterized by large surface area, as well as numerous ordered one-dimensional channels, whose size and shape are designable/controllable [27]. The specific surface area of 3D COFs is noticeably higher than that of 2D COFs, because of their building block containing $\mathrm{sp}^{3}$ carbon or silane atom [25]. Recently, a 3D COF with a record high surface area $\left(S_{B E T}=5083 \mathrm{~m}^{2} / \mathrm{g}\right)$ was reported by the Baldwin's group [30]. However, three-dimensional covalent organic frameworks are less common, due to the confined diversity of the tetrahedron-type knots [27].

The present review, considering the strong necessity for environmental remediation, as well as the eminent potential of covalent organic frameworks as multivalent functional materials in this field, focuses principally on the COFs' environmental applications. Emphasis is placed on the removal of heavy metals from wastewater, as well as on the existing challenges, such as competitive systems, large-scale industrial application, biocompatibility, and potential future directions.

\section{Synthetic Methodologies for Covalent Organic Frameworks}

Recently, different synthetic routes have been reported for the development of COFs, since the first successful synthesis of COFs through solvothermal, ionothermal, roomtemperature, and microwave synthesis [27,31-33]. However, synthesizing COFs, characterized by enhanced porosity and crystallinity at the same time, is quite stimulating; as a result, appropriate temperature, pressure, as well as combining solvents are very crucial, in order to balance the development and crystallization of the COFs' framework [34,35]. In general, covalent organic frameworks are being used either as a bulk material or as a thin film attached to a support surface [34,36]. Apart from direct COFs' crystallization [29], reversible condensation reactions, such as Knoevenagel, spiroborane, and imide, are often utilized for developing COFs characterized by crystallinity [34,37,38]. More methods for COFs' fabrication have been developed, including vapor-assisted conversion and sono-chemical synthesis [27,39]. 
The characterization of COFs takes place through traditional materials science techniques such as powder XRD, BET, electron microscopy, and thermal analysis. Depending on the pore size and the arrangement of the ligands, the COFs exhibit characteristic and in certain cases sharp diffraction peaks in their XRD patterns that translate to certain $p-p$ stacking, A-B and A-A stacking, and intramolecular distances. BET is routinely employed for the evaluation of their porous capacity.

\subsection{Selection of Functional Side Groups}

Several kinds of linkages have been reported (Figure 1). These linkages have a great impact on the stability and physical chemical properties of COFs, for example their electrochromism and luminescence $[27,40]$. The main benefits and drawbacks of each type of linkage are summarized in Table 1. For instance, even though COFs based on boroxine or boronate-ester linkages are luminescent, they are not stable in the presence of water molecules, due to the electron-deficient nature of boron [27]. On the other hand, imine-based COFs are characterized by improved stability, but their majority is not lightemitting owing to dissipation of excitation energy triggered by the nitrogen atoms through photo-induced electron transfer [27,41,42].

Recently, $\mathrm{C}=\mathrm{C}$ linkages have been developed for the fabrication of covalent organic frameworks with enhanced stability and luminescent activity $[27,40]$. In addition, unsubstituted olefin (-CH=CH-)-linked COFs present good stability and crystallinity at harsh acidic and alkaline conditions $[27,43]$.

Another class of COFs feature boronate ester linkages and exhibit excellent crystallinity and porosity values [29]. COFs that contain boron-type linkages are characterized by enhanced photoconductivity, surface area, crystallinity, and thermal stability, but they are quite sensitive to moist environments, a feature that limits their applications [34]. Various methods have been reported, in order to improve the hydrolytic stability of COFs having boron-containing linkages, such as synthesis from alkylated edge units, post-synthesis alterations, as well as development of spiroborate-linked COFs by condensing diol with boron hydride with anionic boron centers [29,34,44,45].

Imine linkage constitutes the most extensive approach for the synthesis of covalent organic frameworks in several organic solvents, such as mesytilene, dioxane, dioxaneaqueous acetic acid, acetic acid $(\mathrm{AcOH}), 1$-butanol $(\mathrm{n}-\mathrm{BuOH})$, and orthodichlorobenzene (o-DCB) [25]. Imine-based COFs are synthesized through the co-condensation of amines and aldehydes $[34,46]$. COFs, characterized by the presence of imine groups, can chelate with heavy metal ions thanks to the abundant nitrogen, and they have potential for various applications as catalyst supports $[25,34,44]$. In addition, they are quite stable in water and acidic or alkaline conditions, as well as in organic solvent compared to boron-based COFs; nevertheless, they feature inferior or comparable crystallinity [34]. Imine linkages demonstrate low $\pi$-delocalization due to the enhanced polarization of nitrogen atoms [34]. Both physicochemical and crystal stability of imine-linked covalent organic frameworks are able to be improved through the insertion of $-\mathrm{OH}$ to Schiff base centers $(\mathrm{C}=\mathrm{N})$ and the development of intramolecular hydrogen bonds (i.e., $\mathrm{O}-\mathrm{H} \cdots \mathrm{N}=\mathrm{C}$ ) $[25,29,47,48]$.

COFs' synthesis utilizing hydrazone linkages comprises an easily controllable, $\mathrm{pH}$ dependent, and reversible synthetic route [25]. The hydrazone-linked covalent organic frameworks are developed by the co-condensation of hydrazides and aldehydes [34]. Hydrazone linkage owing to hydrogen-bonding interactions on linker sites can enhance the COFs' stability [29]. However, due to the rather weak interlayer interactions in hydrazonelinked COFs, they can be exfoliated into thin films under moderate conditions [34].

COFs characterized with imide linkages have been synthesized through the condensation of amine and dianhydride in various reports $[29,49]$, also as materials with phenazine linkages through condensation reactions [29].

COFs have also been synthesized through condensation of hydrazine and aldehyde based on azine linkage, in order to improve the pore size and integrate organic building 
blocks into long ordered 2D layers or 3D networks, precisely [8]. Azine-linked COFs present robust linkage, enhanced porosity, and improved thermal and chemical stability [25,29].

$\therefore \mathrm{X}_{\mathrm{OH}}^{\mathrm{OH}}+\cdots \mathrm{B}_{\mathrm{B}(\mathrm{OH})_{2}} \rightarrow \cdots$

(a)<smiles>Cc1ccc(NN(Nc2ccc(C)cc2)Nc2ccc(C)cc2)cc1</smiles>

(c)

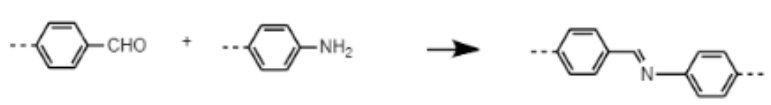

(e)

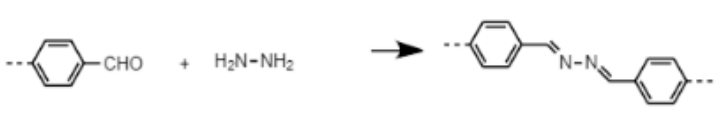

(g)

$$
\mathrm{SO}_{0}+\mathrm{Cl}_{\mathrm{NH}_{2}}^{\mathrm{NH}_{2}} \rightarrow \mathrm{N}_{\mathrm{N}}^{\mathrm{N}}
$$

(i)

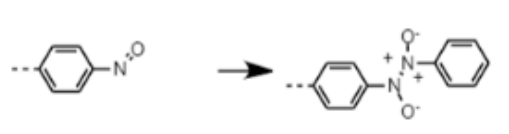

(k)

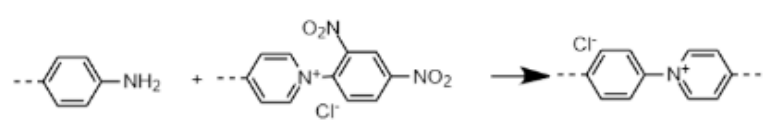

(m)

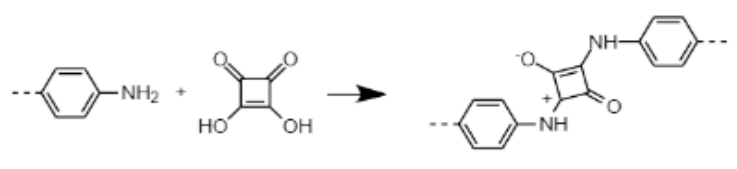

(o)

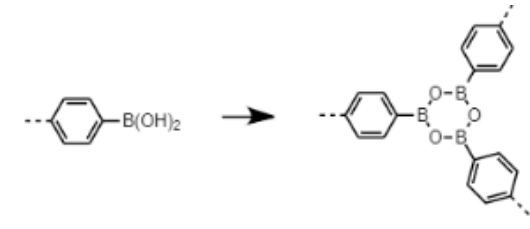

(b)

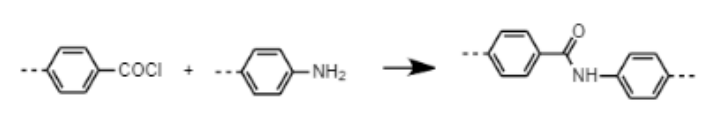

(d)

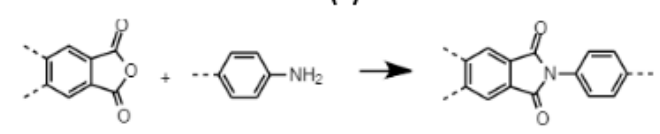

(f)

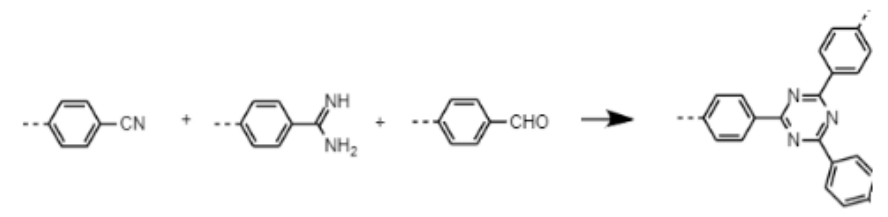

(h)

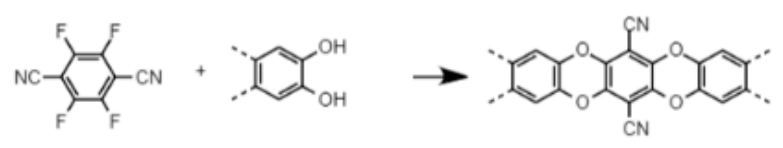

(j)

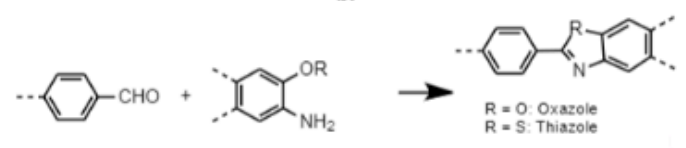

(I)

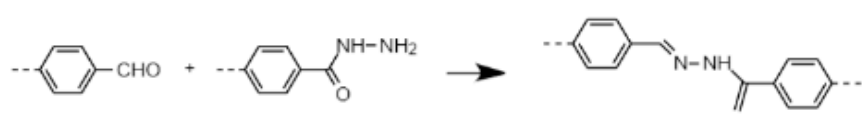

(n)

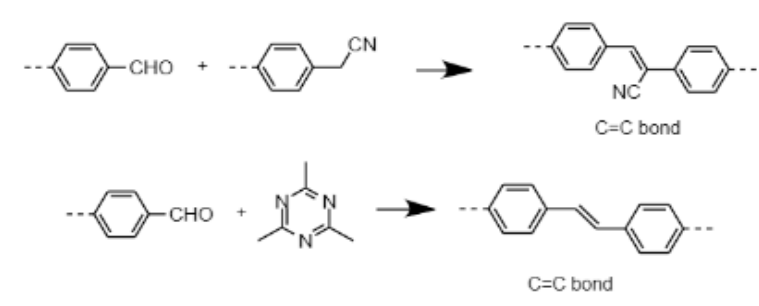

(p)

Figure 1. Typical dynamic covalent bonds used to synthesize COFs: (a) boronate ester, (b) boroxine, (c) borazine, (d) amide, (e) imine, (f) imide, (g) azine, (h) triazine, (i) phenazine, (j) dioxin, (k) azodioxide, (l) oxazole/thiazole, (m) viologen, (n) hydrazone, (o) squaraine, and (p) $\mathrm{C}=\mathrm{C}$ bond.

Compared to imine-, azine-, and hydrazone-linked covalent organic frameworks, those having triazine or phenazine linkages present improved chemical stability, as well 
as extended conjugated networks, features that offer them the potential to be utilized in photocatalytic applications [34].

Covalent organic frameworks, characterized by keto-enol linkages, are synthesized via interaction of enol-imine and keto-enamine under irreversible photon tautomerism.

The double bond between carbon atoms in linking groups has also been explored regarding the development of fully conjugated COFs $[29,43,50-54]$. The resulting sp $\mathrm{sp}^{2} \mathrm{c}$ COFs consist of all $\mathrm{sp}^{2}$ carbon backbones and constitute ultra-stable frameworks that maintain both their crystallinity and porosity in water, harsh acidic or alkaline media, and extended exposure to air [29,34,40]. As compared with COFs possessing imine linkages, $\mathrm{sp}^{2}$ c COFs are attractive because of their stability and the development of conjugated structures, in order to increase electron delocalization, as well as charge transfer. Nevertheless, the synthesis of crystalline $\mathrm{sp}^{2}-\mathrm{c}$ covalent organic frameworks with optative conjugation is complicated owing to the insignificant reversibility of $C=C$ bonds $[29,34]$.

It is worth mentioning that post-synthetic modifications can be utilized, in order to alter one type of COFs' linkage to another one, which is inaccessible to direct polycondensation $[34,55]$. These modifications can be fulfilled by (i) the introduction of metal complexes, (ii) the development of covalent linkages with incoming groups, (iii) a monomer truncation strategy, and (iv) the chemical alteration of linkages [34]. For instance, COFs presenting imine linkages can be oxidized (hydrogen perchloride-mediated oxidation) into amide linkages $[29,56]$, while the reduction of imine linkages, using sodium borohydride, leads to the development of amine-linked covalent organic frameworks [29,34,57]. Moreover, imine-linked COFs have been altered to oxazole- and thioazole-linked ones. In the latter case, the alteration is conducted through the reaction of COFs with sulfur at a high temperature $\left(350^{\circ} \mathrm{C}\right)[29,46,58]$.

Table 1. Main benefits and drawbacks of COFs' linkages.

\begin{tabular}{|c|c|c|}
\hline Type of Linkage & Benefits & Drawbacks \\
\hline $\begin{array}{l}\text { Boronate } \\
\text { Boroxine }\end{array}$ & . Thermal stability [28] & $\begin{array}{l}\text { - Prone to amorphization or disintegration } \\
\text { upon contact with water or protic } \\
\text { solvents [59]. }\end{array}$ \\
\hline Imine & $\begin{array}{l}\text { Enhanced hydrothermal stability }[59,60] \text {. } \\
\text {. High chemical stability under harsh acidic } \\
\text { conditions [60]. }\end{array}$ & $\begin{array}{l}\text {. Lower crystallinity compared to } \\
\text { boronate-linked and phenazine-linked } \\
\text { COFs [28]. }\end{array}$ \\
\hline Hydrazone & $\begin{array}{l}\text {. Easily controllable, } \mathrm{pH} \text {-dependent and reversible } \\
\text { synthetic route [25]. } \\
\text {. Improved stability [29]. }\end{array}$ & $\begin{array}{l}\text { Exfoliation into thin films under mild } \\
\text { conditions, due to weak interlayer } \\
\text { interactions [34]. }\end{array}$ \\
\hline Imide & . High porosity [28] & $\begin{array}{l}\text { - Require high temperatures during } \\
\text { synthesis [28]. }\end{array}$ \\
\hline Azine & $\begin{array}{l}\text {. Enhanced thermal stability }[25,29] \text {. } \\
\text {. Resistant to hydrolysis in both acidic and basic } \\
\text { media }[28,32] \text {. } \\
\text {. Production of COFs with narrow pore sizes [59]. }\end{array}$ & $\begin{array}{l}\text {. Less chemical stability than triazine or } \\
\text { phenazine linkages [34]. }\end{array}$ \\
\hline Phenazine & $\begin{array}{l}\text {. Stable in various solvents }[16,28] \text {. } \\
\text {. Extended conjugated networks [34]. } \\
\text {. High crystallinity [28]. } \\
\text { - High porosity [28]. } \\
\text { - Synthesis at room temperature [28] } \\
\text {. Extended conjugated networks [34]. }\end{array}$ & \\
\hline $\mathrm{sp}^{2}-\mathrm{c}$ & $\begin{array}{l}\text { - Ultra-stable frameworks }[29,34] \text {. } \\
\text { - Maintenance of crystallinity and porosity in water, } \\
\text { acidic/alkaline media, and prolonged exposure to } \\
\text { air }[29,34,40] \text {. }\end{array}$ & $\begin{array}{l}\text {. Complicated synthesis, due to poor } \\
\text { reversibility }[29,34] \text {. }\end{array}$ \\
\hline
\end{tabular}




\subsection{Synthetic Methods of Covalent Organic Framworks}

\subsubsection{Solvothermal Synthesis}

The majority of COFs are synthesized under solvothermal conditions, which is similar to the synthesis of metal organic frameworks (MOFs) and inorganic zeolites in autoclave [31]. Most of the COFs synthesized through solvothermal routes often require heating at elevated temperature (usually $120^{\circ} \mathrm{C}$ ) for several days under Schiff-base chemistry [60], while ligand exchange has also been explored [61]. The solvothermal method involves a mixed reaction founded on organic or non-aqueous solution that comprises the solvent and takes place in a closed system under a given temperature and pressure [62]. Both temperature and pressure of the reaction system strongly affect COFs' crystallinity and porosity [34,35]. The reaction process is usually conducted under heating at temperatures varying from 80 to $120^{\circ} \mathrm{C}$, depending on the chemical reactivity of building units [62], in a sealed vessel for two to nine days [31,34,36,62]. For obtaining improved yield and performance, the reaction time for COFs' synthesis is three days minimum [62]. Finally, the precipitate is collected, suitable solvents are used for washing, and then it is dried under vacuum, in order to obtain solid powder of COFs [31,63].

Another crucial parameter for the formation of COFs is the selection of the solvent since it has a strong impact on the reactant solubility, which can be related to the rate of the reaction and the crystal growth, crystal nucleation, as well as the self-healing structure [34,64]. Mixtures containing two solvents are usually used, in order to fabricate COFs utilizing an acidic catalyst $[34,65]$. However, the appropriate selection of a suitable solvent system for the development of crystalline-structured COFs is still a challenge [34]

Despite the fact that the solvothermal synthetic route is widely applied for the development of COFs and frequently results in satisfactory quality of the products, it presents some limitations. The main drawback is the difficult scale-up to industrial applications, due to the high temperature/pressure and the very slow reaction rates in many COFs' syntheses [31,34]. Additionally, some COFs, featuring borate or boroxine linkages, are not stable in moist environments, comprising a challenge for application in this field [31,34].

\subsubsection{Ionothermal Synthesis}

In the ionothermal synthetic method, COFs are fabricated utilizing molten salts or ionic liquids that act as solvents or catalysts $[34,66]$. Ionic liquids present a plethora of benefits regarding other organic solvents for the development of COFs characterized by high periodicity and stability, because of their reusability. These properties can be modified through counter anions $[34,67,68]$.

Ionothermal interaction usually takes place at high temperatures (about $400^{\circ} \mathrm{C}$ ), which restricts the application of various monomers [66]. In addition, building monomers can be decomposed at high temperatures, while unwanted side reactions and by-products can be produced too $[34,66]$. Another drawback regarding this synthetic approach is that the applied monomers are amorphous and do not possess molecular orderings [66]. Thus, ionothermal synthesis has not yet been well-applied in large-scale practical production so far [31].

\subsubsection{Microwave-Assisted Synthesis}

Microwave-assisted synthesis constitutes an alternative synthetic method towards solvothermal and ionothermal methods, which utilizes microwave irradiation as an alternative energy source [66]. It has already been found that microwaves can be used in the synthesis of crystalline COF materials $[31,69,70]$. Microwave heating presents several benefits in comparison to conventional heating methods, including accelerated reaction rates, higher product yields, cleaner products, lower energy usage, milder reaction conditions, as well as enhanced selectivity during the chemical reactions $[31,34,62,66]$, offering the possibility for industrialized production of COFs in the future.

Using the microwave method, it is possible to follow the reaction's progress and control the reaction temperature and pressure simultaneously [66]. With respect to the 
above, COFs characterized by high crystallinity and high stability have been successfully synthesized through microwave-assisted solvothermal and ionothermal methods [31].

\subsubsection{Room-Temperature Synthesis}

Room-temperature synthetic routes exhibit a plethora of advantages, particularly in the case of sensitive monomers or substrates [34]. More specifically, the as-synthesized $\mathrm{COFs}$ are characterized by thermal and acid-base stability, high surface area, and enhanced adsorption capacity $[62,66]$; however, despite the feasibility of preparing COFs under ambient conditions, the large-scale synthesis and application of these COFs is limited and challenging, due to the use of expensive reagents, such as ionic liquids and metal-triflate catalysts [34,62].

Room-temperature synthesis consists mainly of two techniques, the mechanochemical grinding and the solvent method. Mechanochemical synthesis constitutes a facile, economical, solvent-free, and environmentally friendly method [34,71]. COFs, developed through mechanochemical grinding, are characterized by poor crystallinity, porosity, and surface areas, compared to those synthesized via the solvothermal synthetic route [34].

\subsubsection{Other Methods}

The sono-chemical synthetic route constitutes an alternative approach to the solvothermal synthesis [29]. More specifically, ultrasounds are applied to the reaction system for the development and the collapse of bubbles in the solution, which can affect the cavities of the COFs' structure, as well as they have the ability to accelerate the crystallization process rate, because of the acoustic cavitation $[29,66]$. Acoustic cavitation produces extremely high local temperatures $(>5000 \mathrm{~K})$ and pressures $(>1000 \mathrm{bar})$, leading to exceedingly fast heating and cooling rates [66]. In addition, the reaction can be conducted on a relatively large scale $(0.5 \mathrm{~L})$, that is quite larger than the conventional batches $(1-40 \mathrm{~mL})$, which are being utilized in the solvothermal method [29]. Inferentially, this method is fast, as it can shorten the reaction time from 3 days to $1-2 \mathrm{~h}$, due to the absence of an induction period $[29,66]$, it is economical, and it consists of a green synthetic method.

For the synthesis of covalent organic frameworks, a vapor-assisted solid-state technique has also been developed [29]. During this synthetic route, the monomers are dissolved in a polar solvent and the resulting mixture is placed dropwise on a glass substrate. Afterwards, the substrate is placed in a desiccator, at room temperature, that contains a vessel of reaction solvent. After approximately $72 \mathrm{~h}$, the glass substrate is covered with the COF layer. The film's thickness can be precisely regulated, indicating a range from a few hundred nanometers to several microns [29].

Ionic liquids have been utilized as a reaction media for the development of both 2D and 3D covalent organic frameworks featuring imine linkages and displaying enhanced crystallinity under moderate conditions [29,31,35]. Ionic liquids comprise molten organic salts that are characterized by low melting points. They are environmentally friendly, non-volatile, and non-flammable, while their physicochemical properties can be easily modified through careful selection of their counter ions. The usage of ionic liquids as reaction media may derive from the fact that an ionic environment facilitates the alignment of aromatic building blocks to an ordered structure. Relatively to the solvothermal synthetic route that is quite time-consuming, the synthesis utilizing ionic liquids is facile, fast, and cost-effective [29].

The Knoevenagel condensation constitutes a widely utilized organic process for the conversion of aldehydes or ketones $(\mathrm{C}=\mathrm{O})$ to preferential olefins in the cyano-substituted and cis-configurations, as the base for the catalyst [31]. Very recently, the synthesis of cyanovinylene-linked covalent organic frameworks through Knoevenagel condensation of multidentate benzylcyanides (acting as $\mathrm{C}-\mathrm{H}$ acids) with dialdehydes has been reported [31,54,72]. 


\section{Heavy Metal Removal Applications}

\subsection{Removal of Mercury}

Taking into account the exceptional binding affinity between sulfur derivatives and $\mathrm{Hg}^{2+}$, various kinds of sulfur-containing COFs have been synthesized and characterized by good adsorption capacities and selectivity for $\mathrm{Hg}^{2+}$ ions [27] (Table 2). $\mathrm{Hg}^{2+}$ tends to form stable compounds with electron-donating elements (e.g., $\mathrm{S}$ to form $\mathrm{HgS}$ ), as well as ligands containing phosphorus, nitrogen, and oxygen, in order to fill the vacant $6 \mathrm{~s}$ orbital; however, at high temperatures $\left(>400^{\circ} \mathrm{C}\right)$, mercury sulfide is not stable and decomposes to its metallic form $[73,74]$.

According to the theory of hard-soft acid and base, soft bases tend to develop stable complexes with soft acids, while hard bases tend to form stable complexes with hard acids. As for mercury and sulfur, the latter constitutes a soft base that binds covalently to mercury, which comprises the soft acid, as it is characterized by a relatively large ionic size, low electro-negativity, and high polarizability $[73,75]$.

In 2017, Merí-Bofí and coworkers [76] studied a well-designed COF, characterized by the presence of triazole and thiol groups in its cavities, as a potential sorbent material for $\mathrm{Hg}^{2+}$. Triazole and thiol groups were incorporated under moderate conditions into a highly porous organic polymer TPB-DMTP-COF (TPB, triphenylbenzene; DMTP, dimethoxyterephthaldehyde), with good yield. The as-prepared novel material had the ability to adsorb $\mathrm{Hg}^{2+}$ ions, both from low and highly concentrated solutions, with exceptional efficiency. More specifically, the material could efficiently reduce mercury concentration from $10 \mathrm{mg} / \mathrm{L}$ to $1.5 \mu \mathrm{g} / \mathrm{L}$, a value that is lower than the acceptable limits in drinking water standards ( $2 \mu \mathrm{g} / \mathrm{L})$; inferentially, the synthesized imine-based COF indicated an ultra-high affinity for $\mathrm{Hg}^{2+}$ ions with outstandingly fast kinetics. This material is offering new perspectives for the utilization of such covalent organic frameworks in mercury removal and environmental remediation applications.

During the same year of 2017, Sun et al. [77] developed a two-dimensional mesoporous covalent organic framework featuring dense and flexible thiol and thioether chelating arms. The as-synthesized COF indicated very high $\mathrm{Hg}^{0}$ and $\mathrm{Hg}^{2+}$ adsorption capacity, 863 and $1350 \mathrm{mg} / \mathrm{g}$ respectively, a high affinity for $\mathrm{Hg}^{2+}$ with impressive distribution coefficient values at a wide $\mathrm{pH}$ range from 3 to 10 , as well as exceptionally fast kinetics for the adsorption of $\mathrm{Hg}^{2+}$. Their results verified the great potential of covalent organic frameworks as an adsorbent material towards $\mathrm{Hg}^{2+}$.

Leus and co-workers in 2018 [78] synthesized a composite material consisting of a covalent triazine framework (denoted as CTF-1) hosting $\mathrm{Fe}_{2} \mathrm{O}_{3}$ (in the maghemite $\gamma-\mathrm{Fe}_{2} \mathrm{O}_{3}$ phase) nanoparticles. The adsorption capacity of $\gamma-\mathrm{Fe}_{2} \mathrm{O}_{3} @ \mathrm{CTF}-1$ reached $165.8 \mathrm{mg} / \mathrm{g}$ for $\mathrm{Hg}^{2+}$, which is significantly higher compared to pure covalent triazine frameworks and other iron-based materials. The as-prepared composite material could also be reused for several cycles, maintaining good adsorption capacity.

Moreover, Fu et al. [79] presented a novel technology for the fabrication of porous covalent polytriazines with rich sulfur contents $(13.2 \mathrm{wt} \%)$. The synthesized networks were characterized by enhanced physical and chemical stability, as well as high adsorption capacity and removal efficiency towards mercury ions, even at very low initial concentrations; thus, these CTFs constitute promising adsorbent materials for wastewater treatment and water decontamination applications.

In 2019, Mondal and co-workers [80] fabricated a thioether-functionalized covalent triazine network (SCTN-1) through an ionothermal method, which indicated an exceptionally high $\mathrm{Hg}^{0}$ and $\mathrm{Hg}^{2+}$ adsorption capacity ( 813 and $1253 \mathrm{mg} / \mathrm{g}$, respectively). These researchers demonstrated that the removal of toxic mercury, using the synthesized organic porous material, is subserved by a facile operational process, fast adsorption kinetics, high distribution coefficients, as well as ease of regeneration of the adsorbent. The aforementioned characteristics render these COFs a quite promising adsorbent material towards $\mathrm{Hg}^{2+}$ (Figure 2). 


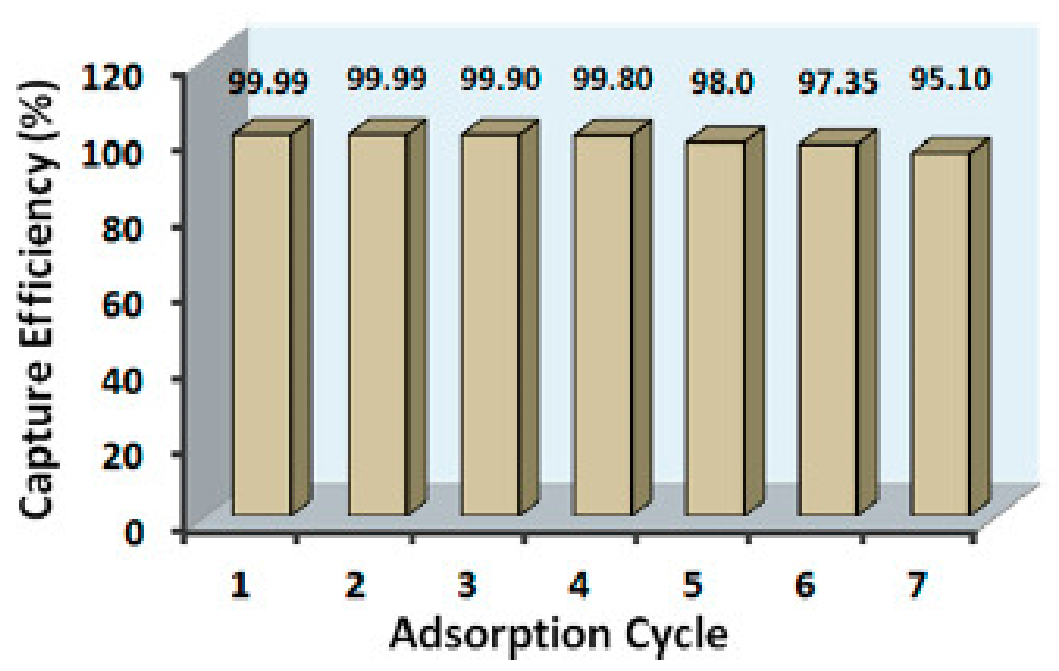

Figure 2. Recyclability performance for $\mathrm{Hg}^{2+}$ removal in aqueous solution (Reprinted with permission from Mondal S, Chatterjee S, Mondal S, Bhaumik A, ACS Sustainable Chem. Eng. 2019; 7: 7353-7361 [80]. Copyright (2019) American Chemical Society).

Additionally, Wang et al. [81] used a porous covalent organic framework as a support for the in-situ growth of silver $(\mathrm{Ag})$ nanoparticles through a facile one-step solution infiltration method. The as-prepared AgNPs@COF material proved to be a quite promising adsorbent for $\mathrm{Hg}^{2+}$ ions from an acidic solution, regarding its fast adsorption kinetics, its high adsorption capacity, its very high $\mathrm{Ag}$ atom utilization, its enhanced stability and selectivity, as well as its reusability; therefore, this material offers new prospects for the utilization of covalent organic frameworks as supporting platforms for the immobilization of metal nanoparticles that could be used in acidic wastewater treatment applications.

He et al. [82] fabricated a novel covalent organic framework polymer through Suzuki polymerization of two monomers based on triarylamine derivatives. On the basis of that polymer, they further developed a Schiff base COF polymer fluorescent sensor for efficient detection and removal of $\mathrm{Hg}^{2+}$ ions.

Tao and his co-workers, in 2020, reported the synthesis of a porous $\mathrm{SO}_{3}$-anchored covalent organic framework for $\mathrm{Hg}^{0}$ and $\mathrm{Hg}^{2+}$ adsorption [83]. The results indicated that the as-prepared material presents ultrahigh adsorption capacity for both $\mathrm{Hg}^{0}$ and $\mathrm{Hg}^{2+}$, fast adsorption kinetics, strong binding affinity, high selectivity, and good reusability.

Moreover, Panda et al. [84] developed a novel, metal-free, fluorescent covalent organic framework acting as a chemosensor for the simultaneous detection and removal of $\mathrm{Hg}^{2+}$ ions (Figure 3). More specifically, the fabricated COF was characterized by extended $\pi$ conjugation and large pore size, presenting the ability to act as a highly durable sensor for the detection of $\mathrm{Hg}^{2+}$, as well as high removal efficiency equal to $99.8 \%$ (pH = 7, 273 K). Additionally, this material currently constitutes one of the few metal-free sensors and adsorbents available, able to be utilized in several industrial wastewater treatment applications.

Furthermore, in 2020, Ma and his research team [85] developed a sulfhydryl (-SH)modified COF by a one-step reaction for the removal of $\mathrm{Hg}^{2+}$ ions from water. The synthesized covalent organic framework exhibited high adsorption capacity $(1283 \mathrm{mg} / \mathrm{g})$ towards $\mathrm{Hg}^{2+}$ ions, with a value more than 25 times higher than that of the COF without the presence of $-\mathrm{SH}$. The material exhibited fast adsorption kinetics, attaining removal equal to $95 \%$ of $1000 \mu \mathrm{g} / \mathrm{L} \mathrm{Hg}^{2+}$ within $30 \mathrm{~min}$ and above $99 \%$ after $2 \mathrm{~h}$. Furthermore, it exhibited removal efficiency of more than $99 \%$, under a wide $\mathrm{pH}$ range, as well as selectivity towards $\mathrm{Hg}^{2+}$ ions' adsorption in the presence of other metal cations. As a result, the aforementioned COF-SH material has great potential for $\mathrm{Hg}^{2+}$ removal from water and wastewater samples under complex conditions (Figure 4). 


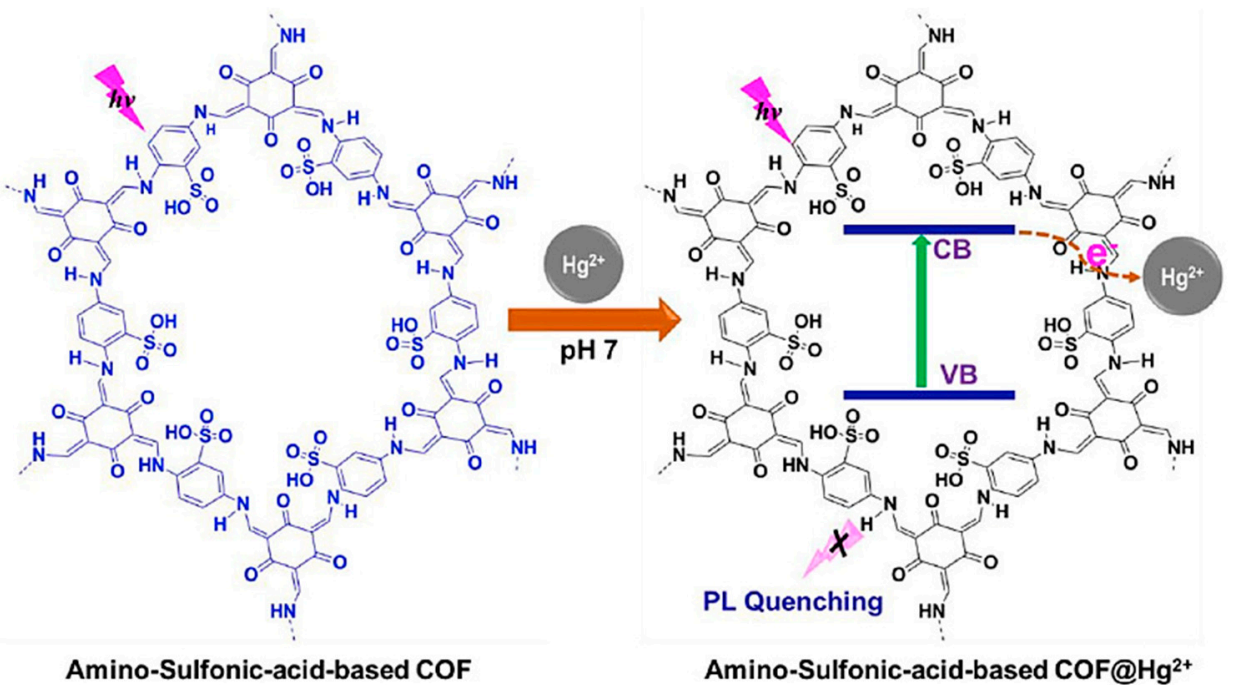

Figure 3. The interaction mechanism of COF and $\mathrm{Hg}^{2+}$ (Reprinted with permission from Panda A, Yang Y, Venkateswarlu S, Son Y, Bae T.-H, Yoon M, Microporous Mesoporous Mater, 2020; 306: 110399 [84]. Copyright (2020) Elsevier).

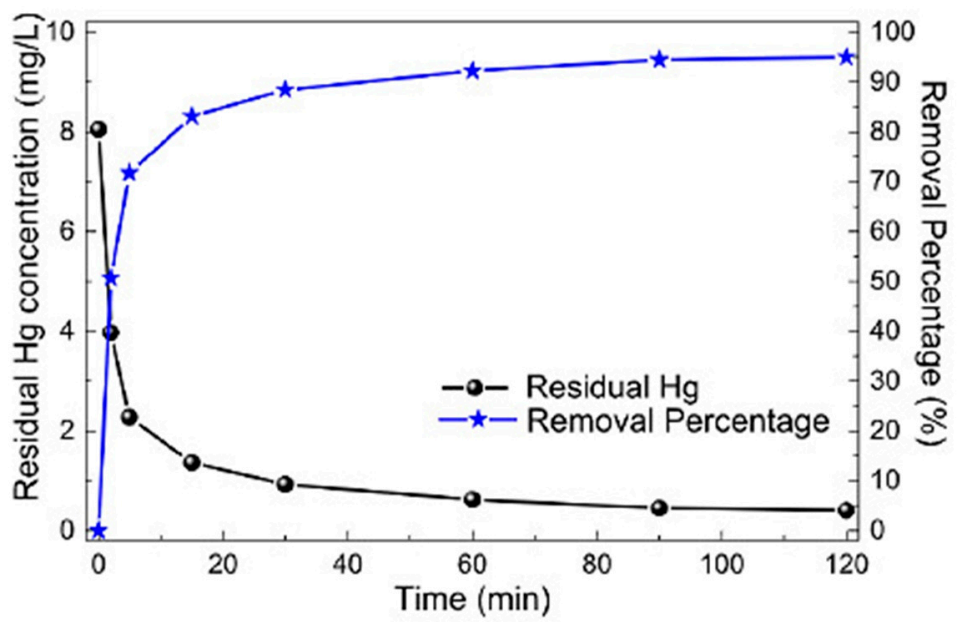

Figure 4. Adsorption kinetics of COF-SH for simulated real $\mathrm{Hg}$-contaminated water. Initial $\mathrm{Hg}^{2+}$ concentration $8.05 \mathrm{mg} / \mathrm{L}$, initial solution $\mathrm{pH} 7.0$, and adsorbent dosage $0.1 \mathrm{~g} / \mathrm{L}$ (Reprinted with permission from Ma Z, Liu F, Liu N, Liu W, Tong M, J Hazard Mater, 2020; 124190 [85]. Copyright (2020) Elsevier).

Finally, Yu et al. [86] reported the synthesis of a reaction-based recyclable fluorescent covalent organic framework, functionalized by allyl together with hydroxy groups $(\mathrm{AH}-$ $\mathrm{COF}$ ), for the detection and effective removal of $\mathrm{Hg}^{2+}$ ions and suitable for utilization in noxious wastewater treatment applications.

\subsection{Removal of Lead}

The main anthropogenic sources of lead ions $\left(\mathrm{Pb}^{2+}\right)$ are battery, smelting, mining, and plating industries, plus ceramic glass industries [87-89]. The reported $\mathrm{Pb}^{2+}$ toxicity is fatal to living organisms, damaging human brain, liver, kidneys, and reproductive system $[87,88]$. Higher amounts of lead accumulation in fresh water may pose health risks and an increase in diseases, such as encephalopathy and hepatitis $[87,90,91]$. The acceptable limits are $0.05 \mathrm{mg} / \mathrm{L}$, as set by the US Environmental Protection Agency, and $0.01 \mathrm{mg} / \mathrm{L}$, which is regulated by the European Union Countries [87].

In 2018, Gupta and co-workers [92] synthesized an ionic covalent organic framework for the removal of $\mathrm{Pb}^{2+}$ ions from aqueous solutions through an ion exchange process. 
Their study suggested that the synthesized COF material might be an intriguing candidate for water-decontamination applications (Table 2).

Additionally, in 2018, Zhang et al. [93] synthesized a TAPB-DMTP-COF (TAPB, 1,3,5tris (4-aminophenyl)benzene; DMTP, 2,5-dimethoxyterephaldehyde) as a novel electrochemical sensor for the detection of $\mathrm{Pb}^{2+}$ ions in an aqueous medium. $\mathrm{Pb}^{2+}$ ions were bound to the TAPB, DMTP-modified covalent organic framework's surface through complexation with amine groups. Given the COFs' exceptional structural characteristics, the designed sensor demonstrated both fast electron transfer rate and high lead adsorption capacity. The as-developed composite COF material indicated a broad linear range, low detection limit, improved sensitivity, good stability, as well as reproducibility, due to its active sites and high surface area. The authors concluded that the aforementioned features suggest that COF-based sensors will constitute an asset in clinical diagnostics and environmental remediation.

Li et al. [26] fabricated two amide-based covalent organic framework materials through a polymerization reaction of acyl chloride and amino groups via mechanochemical ball-milling at room temperature, in order to be utilized as $\mathrm{Pb}^{2+}$ adsorbents. More specifically, for the COFs' synthesis, two types of diamine monomers were chosen, characterized by different framework structure, as well as functional groups (i.e., COF-TP from aromatic diamine monomer of p-phenylenediamineand COF-TE from linear diamine monomer of ethylenediamine). The as-developed COF materials presented a typical lamellar structure, while the amide groups on COFs' skeleton were confirmed to act as active adsorption sites for $\mathrm{Pb}^{2+}$ ions. COF-TE presented greater $\mathrm{Pb}^{2+}$ adsorption capacity than COF-TP, due to the fact that the smaller aromatic skeleton and weak $\pi-\pi$ stacking of the former facilitates higher internal diffusion of $\mathrm{Pb}^{2+}$. In addition, COF-TE was characterized by a higher amide group content, which led to an improved saturated adsorption capacity $(185.7 \mathrm{mg} / \mathrm{g})$, compared to that of COF-TP $(140 \mathrm{mg} / \mathrm{g})$. Finally, they concluded that the enhanced recyclability of $\mathrm{Pb}^{2+}$ adsorption facilitates amide-based covalent organic frameworks as promising $\mathrm{Pb}^{2+}$-adsorbent materials.

$\mathrm{Xu}$ and co-researchers [94] suggested a facile method for the development of covalent organic framework, modified with PVDF (poly (vinylidene fluoride)) ultra-filtration membranes of high $\mathrm{Pb}^{2+}$ removal ability. The removal efficiency of the synthesized $\mathrm{COF}$ membranes was equal to $92.4 \%$, while it was determined at $87.5 \%$ during the fourth reusability cycle. Thus, this novel composite material comprises an efficient medium for the treatment of $\mathrm{Pb}^{2+}$-containing water and wastewater.

Finally, Cao et al. [95] fabricated a novel covalent organic framework via a moderate solvothermal solution-suspension synthetic route for efficient $\mathrm{Pb}^{2+}$ removal from aqueous solution. The synthesized COF material was characterized by a typical lamellar structure, while the sulfhydryl groups on the COF's skeleton were confirmed to act as active $\mathrm{Pb}^{2+}$ adsorption sites. The sulfhydryl-functionalized COF material reached an adsorption equilibrium within $48 \mathrm{~h}$ and presented a maximum $\mathrm{Pb}^{2+}$ adsorption capacity of $239 \mathrm{mg} / \mathrm{g}$, a value much higher than that of conventional adsorbent materials.

\subsection{Removal of Chromium}

Chromium (VI) constitutes one of the major water pollutants, and when it is found at a concentration higher than $100 \mathrm{ppb}$ in drinking water, it is very likely to cause severe damage to living organisms, because of its carcinogenic and mutagenic properties, as well as strong oxidizing power [96].

Taking into consideration the increasing demand for functional materials, which can achieve fast and efficient removal of noxious heavy metals from groundwater and industrial wastewater, Jansone-Popova and co-researchers in 2018 synthesized [96] a novel covalent organic framework solvothermally in a one-step method through a polycondensation reaction. The combination of its building blocks was selected, in order to promote the formation of 2D sheets, in which guanidinium groups were located on the edges of the hexagonal pores. Guanidinium, a positively charged nitrogen analogue of urea, was 
utilized as it is known to develop strong ion pairs with oxoanions due to electrostatic forces and non-covalent hydrogen-bonding interactions. The as-prepared COF material could adsorb 90-200 mg/g of $\mathrm{Cr}^{6+}$ ion, depending on the solution's $\mathrm{pH}$, displaying advanced characteristics among known ion exchange materials and conventional adsorbents.

Cui et al. [97] developed a novel dual-pore covalent organic framework possessing hydroxyl groups, in order to remove hexavalent chromium from aqueous solutions. The prepared material presented fast adsorption kinetics $\left(272 \mathrm{mg} / \mathrm{g} \mathrm{Cr}^{6+}\right.$ within $\left.10 \mathrm{~min}\right)$, as well as a maximum adsorption capacity of the order of $384 \mathrm{mg} / \mathrm{g} \mathrm{Cr}^{6+}$, and this value is among the highest ones reported for porous materials so far.

In 2020, Zhong and co-workers [98] fabricated a magnetic covalent organic framework with $\beta$-ketoenamine linkage through a hydrothermal synthetic route characterized by facile preparation, high stability, enhanced $\mathrm{Cr}^{6+}$ adsorption capacity $(245.45 \mathrm{mg} / \mathrm{g})$ and good reusability (Figure 5). These features make the aforementioned material a potential candidate in environmental remediation applications.

\section{$\operatorname{Cr}(\mathrm{VI})$ adsorption mechanism}

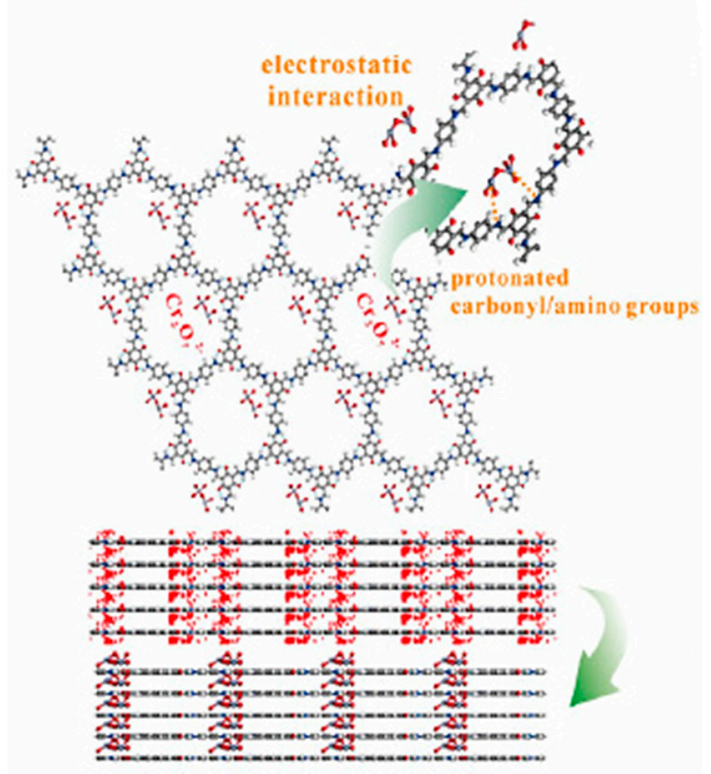

Figure 5. The lowest energy adsorption configuration of $\mathrm{Cr}$ (VI) adsorbed onto the surface of TpPa-1 (Reprinted with permission from Zhong X., Lu Z, Liang W., Hu B., J. Hazard Mater, 2020; 393: 122353 [98]. Copyright (2020) Elsevier).

Finally, also in 2020, Zhu and co-workers [99] successfully synthesized two COFs with different hydroxyl group distributions (COF1 and COF2). Both covalent organic frameworks indicated good $\mathrm{Cr}^{6+}$ adsorption capacity (Table 2) within a wide $\mathrm{pH}$ range and enhanced $\mathrm{Cr}^{6+}$ selectivity in mixed ion solutions, rendering them potential materials for adsorption applications.

\subsection{Removal of Arsenic}

Arsenic (As) constitutes a harmful metalloid and well-known carcinogen, and it is considered one of the most abundant elements in the Earth's crust $[100,101]$. The major sources of arsenic contamination in ecosystems originate from both geogenic and anthropogenic activities, such as natural deposits in rocks and sediments, geothermal water, and environmental pollution. The presence of arsenosulfides and arsenides in the geothermal and marine environments result to the uninterrupted accumulation of noxious As species (organic and inorganic), which comprise a potential threat to terrestrial and aquatic flora and fauna [100]. The distribution and speciation of arsenic in the groundwater is driven by a biological oxidation/reduction process (geochemical cycle) of organic substrates that 
releases arsenic from the hydro-geosphere environments [100,102]. Inorganic arsenite $\mathrm{As}^{3+}$ (reducing) and arsenate $\mathrm{As}^{5+}$ (oxidizing) can induce chronic toxicity to human health through mitigation to food chains, depending on the surrounding geochemical equilibrium systems $[100,102]$. Considering the negative physiological effect of As-exposure on human health and its frequent detection in the groundwater above the World Health Organization maximum contaminant level ( $>10 \mu \mathrm{g} / \mathrm{L})$, it is necessary to develop novel materials for arsenic-decontamination applications.

Taking the aforementioned into account, Leus et al. [78] developed a composite material consisting of a covalent triazine framework (CTF-1) and $\gamma-\mathrm{Fe}_{2} \mathrm{O}_{3}$ nanoparticles. The resulting $\gamma-\mathrm{Fe}_{2} \mathrm{O}_{3} @$ CTF-1 was examined for the adsorption of $\mathrm{As}^{3+}$ and $\mathrm{As}^{5+}$ from synthetic solutions, as well as real surface-, ground-, and wastewater. The prepared composite material indicated great removal efficiency towards both arsenite $(198 \mathrm{mg} / \mathrm{g})$ and arsenate $(102.3 \mathrm{mg} / \mathrm{g})$, which is quite higher than conventional adsorbents, demonstrating its applicability in water decontamination and wastewater treatment applications.

Yang et al. [103] synthesized an EB (Ethidium Bromide)-COF:Br material (Figure 6) as an arsenate adsorbent with high adsorption capacity, while Liu and co-workers [104] fabricated $\mathrm{Fe}^{0} / \mathrm{COFs}$ that exhibited good performance in $\mathrm{As}^{3+}$ adsorption, and the maximum adsorption capacity was $135.78 \mathrm{mg} / \mathrm{g}$. Such composites exhibit a great potential for As removal in wastewater treatment applications.

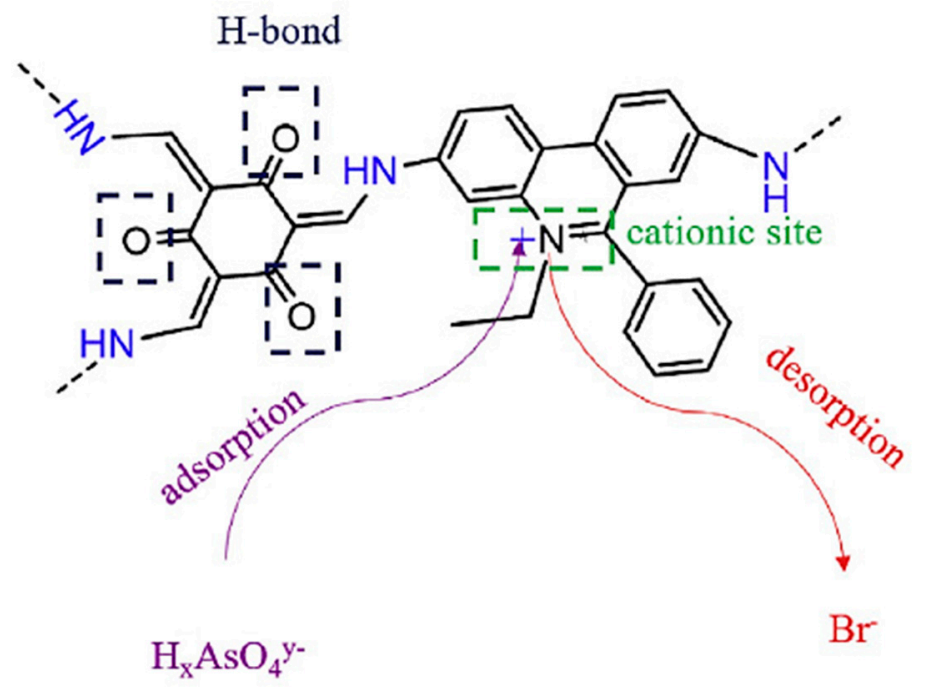

Figure 6. Adsorption interactions between EB-COF:Br and arsenate via electrostatic attraction and hydrogen bonding. $\mathrm{x}=1$ and $\mathrm{y}=2$, or $\mathrm{x}=2$ and $\mathrm{y}=1$ (Reprinted with permission from Yang C.-H., Chang J.-S., Lee D.-J., Chemosphere, 2020; 253: 126736 [103]. Copyright (2020) Elsevier).

\subsection{Removal of Cadmium}

Among heavy metals, cadmium (Cd) constitutes one of the most dangerous heavy metals, as its solubility is greater compared to other heavy metals and it can be easily transferred to the biosystem [105]. Cadmium has been listed as a category-I carcinogen by the International Agency for Research on Cancer and as a group-B1 carcinogen by the US Environment Protection Agency (EPA) [106,107]. Its compounds are noxious and can accumulate in several parts of the human body, such as the nervous, reproductive, renal, and skeletal system, leading to cadmium-related diseases, such as emphysema, kidney failure, itai-itai disease, hypertension, and testicular atrophy [106,108].

In 2019, Liu et al. [108] synthesized a novel heteropore covalent organic framework, in order to be utilized for the adsorption of $\mathrm{Cd}^{2+}$ from aqueous solutions. The produced COF presented ultra-high chemical stability towards water under several $\mathrm{pH}$ values, while it also exhibited hierarchical porosity, enhanced crystallinity, high surface area $\left(1476.5 \mathrm{~m}^{2} / \mathrm{g}\right)$, as well as a plethora of accessible metal ion chelating sites. The as-mentioned COF that 
Liu and his co-researchers developed indicated good recyclability, fast adsorption rates ( $39.6 \mathrm{mg} / \mathrm{g}$ at $1 \mathrm{~min}$ and $95.6 \mathrm{mg} / \mathrm{g}$ in $20 \mathrm{~min}$ ), and an exceptional $\mathrm{Cd}^{2+}$ adsorption capacity (116 mg/g).

Additionally, in 2019, Dinari and Hatami [105] developed a crystalline covalent organic framework enriched with $\mathrm{N}$ via the condensation of 2,4,6-tris(hydrazine)-1,3,5-triazine and 2,4,6-tris(p-formylphenoxy)-1,3,5-triazine to act as a $\mathrm{Cd}^{2+}$ adsorbent from aqueous solutions. The as-prepared COF demonstrated impressive performance regarding $\mathrm{Cd}^{2+}$ adsorption with enhanced capacity, equal to $396 \mathrm{mg} / \mathrm{g}$. In addition, the synthesized material was cost-effective, environment-friendly and highly efficient.

\subsection{Removal of Radioactive Elements}

\subsubsection{Removal of Iodine}

Water contamination with radioactive iodine derives mainly from two sources. The first source is atomic reactors which depend on the fission of uranium atoms, including the production of radioactive iodine as a by-product material [109]. Radioactive iodine is released to the environment from operating nuclear reactors. The second source of radioactive iodine-contaminated wastewater is hospitals, because they use large amounts of radioactive isotopes for diagnostic and therapeutic applications [109].

Yin et al. [110] demonstrated that covalent organic frameworks presented a very high adsorption capacity towards volatile iodine $(4810 \mathrm{mg} / \mathrm{g})$ because of the encapsulation of iodine into the inner cavities and porous shells of the microspheres. Almost $96 \%$ of iodide was adsorbed by COFs after the fifth adsorption-desorption cycle, displaying adequate selectivity and reusability. Additionally, in 2017, Lin and co-researchers [111] synthesized a network with a microporous elastic hydrogen-bonded cross-linked organic framework $\left(\mathrm{H}_{\mathrm{C}} \mathrm{OFs}\right)$. The material demonstrated high adsorption capacity equal to $2900 \mathrm{mg}$ of $\mathrm{I}_{2}$ vapor per gram, as well as a fast equilibrium rate ( $\sim 30 \mathrm{~min})$.

Moreover, in 2018, Wang et al. [112] fabricated five different kinds of two-dimensional covalent organic frameworks with various pore sizes, ranging from 2.2 to $3.3 \mathrm{~nm}$, and observed that the adsorption capacities were improved with the increase of the pore size. Almost $70 \mathrm{wt} \%$ of iodine vapor was captured by $\mathrm{COFs}$, even under moderate temperature, indicating an exceptional adsorption performance. In general, according to their research, the iodine's adsorption mechanism on covalent organic frameworks was mainly induced by Van der Waals interaction and the hydrophobic nature of inner cavities of porous COFs' microspheres.

Then, in 2018 [113], the synthesis of novel COFs was characterized by good stability upon irradiation. The extremely high COFs' uptake capacity $(5.43 \mathrm{~g} / \mathrm{g})$ was attributed to the nitrogen-rich groups and electron-rich $\pi$-conjugated interaction. According to their study, volatile $\mathrm{I}_{2}$ was converted into $\mathrm{I}_{5}{ }^{-}$due to an electron transfer.

$\mathrm{Li}$ and co-researchers [114], utilizing a rapid cryogenic reaction, covalently functionalized an imine-linked two-dimensional covalent organic framework with cotton fiber through an imine condensation reaction. The as-developed COF@cotton fiber material was characterized by a plethora of imine functional groups and dispersed mesoporous holes, features that resulted in the fast adsorption rate and high iodine affinity, characterized by uptake capacities up to $533.9 \mathrm{mg} / \mathrm{g}$.

In 2021, Chen et al. [115] synthesized a crystalline mesoporous nitrogen-containing covalent organic framework through an imine condensation reaction, in order to be utilized as a highly efficient iodine adsorbent (Figure 7). The as-synthesized COF material exhibited a porous structure with high BET surface area $\left(1082 \mathrm{~m}^{2} / \mathrm{g}\right)$, exceptional thermal and chemical stability, and a plethora of nitrogen sites in its skeleton, where an excellent adsorption of iodine (up to $988.17 \mathrm{mg} / \mathrm{g}$ ) took place at room temperature. These results suggest the great potential of the developed COF for addressing the problem of nuclear fission waste contamination that threatens human health. 


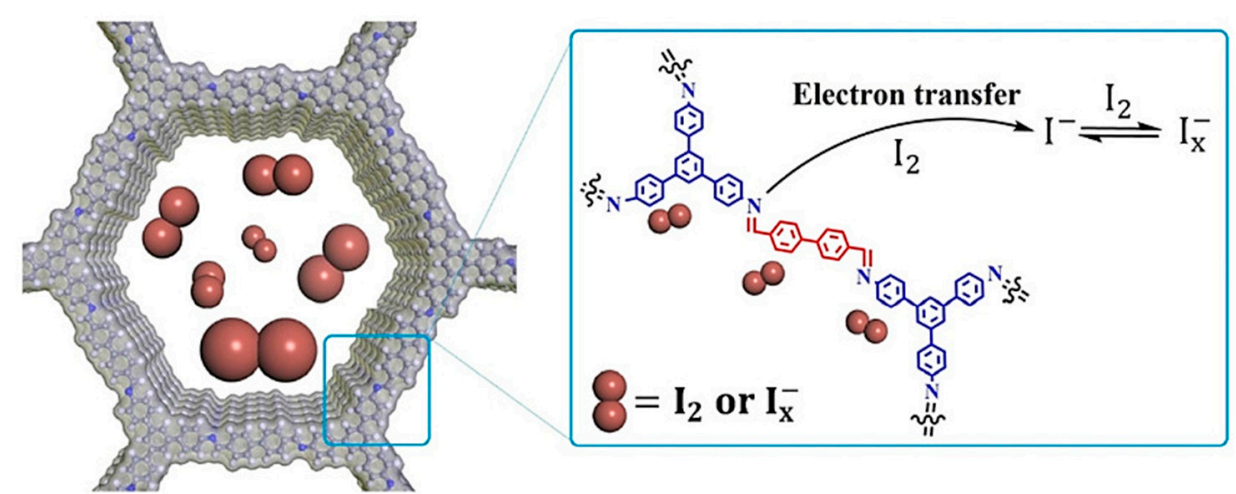

Figure 7. Schematic diagram of iodine adsorption mechanism through an imine-based network (Reprinted with permission from Chen R., Hu T., Li Y., React Funct Polym, 2021; 159: 104806 [115]. Copyright (2021) Elsevier).

\subsubsection{Removal of Uranium}

In 2015, Li et al. [116] fabricated a 2-(2,4-dihydroxyphenyl)-benzimidazole-COF (HBI$\mathrm{COF})$ through a one-step solvothermal synthetic route, presenting a very high $\mathrm{U}(\mathrm{VI})$ adsorption capacity $(81 \mathrm{mg} / \mathrm{g})$. Then, Bai and his co-researchers, in 2016 [117], confirmed that the complexation affinity of $\mathrm{U}(\mathrm{VI})$ with amidoxime groups of AO-functionalized covalent organic frameworks was much stronger than that of cyano- and hydroxyl-groups.

Li et al. [118] proved that PAF-1- $\mathrm{CH}_{2}-\mathrm{AO}$ (amidoxime-functionalized PAF-1) indicated a high adsorption capacity equal to $300 \mathrm{mg} / \mathrm{g}$, while the uranyl concentration decreased from $4.1 \mathrm{ppm}$ to less than $1.0 \mathrm{ppb}$, which was quite below the acceptable limit of the US EPA.

Additionally, in 2018, Wen et al. [119] synthesized AO-COF/graphene composites (oxime-modified graphene-synergized COF or o-GS-COF) characterized by high irradiation and acid stability, because of the $\pi-\pi$ interaction of intra- and inter-layer reactive groups. Their results indicated that $\mathrm{AO}$-modified $\mathrm{COFs}$ could constitute potential candidates for enhanced selective adsorption of $\mathrm{U}(\mathrm{VI})$ in real environmental remediation applications.

Recently, Li et al. [120] demonstrated that COF-TpPa (COF-2,4,6-Triformylphloroglucinol p-Phenylenediamine) displayed good uptake $(152 \mathrm{mg} / \mathrm{g})$ and good reusability towards $\mathrm{U}(\mathrm{VI})$ under the presence of seven different competing ions.

\subsection{Other Metals}

In this section, we will emphasize on the removal of various other metals, except the aforementioned which were the focus of the article (Table 2). In 2018, Zhou and his co-researchers [121] designed a fluorescent covalent organic framework characterized by an accurate distribution of thioether pendant arms inside its cavities as binding sites for $\mathrm{Au}^{3+}$ ions. The $\mathrm{COF}$ was solvothermally fabricated through a reversible imine condensation reaction of 2,5-bis(2-(ethylthio)ethoxy) terephthalohydrazide (BETH) and 1,3,5-triformylbenzene (TFB). The as-mentioned thioether-functionalized COF (TTB-COF) exhibited selective sensing, as well as capture of $\mathrm{Au}^{3+}$ ions at ultra-trace levels in water (Figure 8). It is important to highlight that it presented selective attraction of $\mathrm{Au}^{3+}$ ions over other metal ions, even at very low concentration levels, through significant luminescence quenching via the strong and selective affinity of sulfur atoms towards $\mathrm{Au}^{3+}$ ions.

In addition, in 2018, Lu et al. [122] reported the fabrication of a 3D carboxy-functionalized covalent organic framework (3D-COOH-COF) by post-synthetic alteration of a hydroxyfunctionalized $\mathrm{COF}$, in order to be utilized for the selective extraction of lanthanide ions $\left(\mathrm{Nd}^{3+}, \mathrm{Sr}^{2+}\right.$, and $\left.\mathrm{Fe}^{3+}\right)$. The 3D-COOH-COF indicated enhanced adsorption capacity of the examined lanthanide ions, according to the Langmuir adsorption isotherms, while reusability experiments confirmed that the adsorption uptake of the as-mentioned COF is sparsely decreased. 


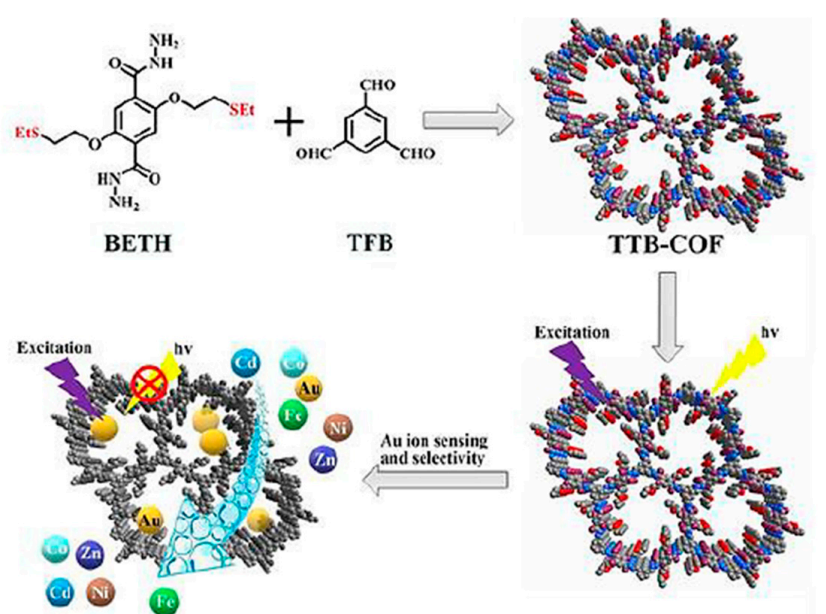

Figure 8. Schematic representation of the synthesis of TTB-COF and its application in selective detection and capture of $\mathrm{Au}^{3+}$ ions (Reprinted with permission from Zhou Z., Zhong W., Cui K., Zhuang Z., Li L., Li L., Bi J., Yu Y., Chem Commun, 2018; 54, 9977-9980 [121]. Copyright (2018) Royal Society of Chemistry).

Cai et al., in 2019 [123], fabricated a fluorescent covalent organic framework utilizing Q-graphene scaffolds through melamine-aldehyde and phenol-aldehyde polycondensation reactions (Figure 9). Cai and his co-researchers found that the synthesized COF displayed high green fluorescence, as well as enhanced stability and $\mathrm{Cu}^{2+}$ ions adsorption capacity. As a result, they developed a fluorimetric strategy, in order to probe $\mathrm{Cu}^{2+}$ ions in blood and wastewater. The prepared covalent organic framework presented improved removal efficiency regarding $\mathrm{Cu}^{2+}$ ions, and low detection limit of $\mathrm{Cu}^{2+}$ ions $(0.50 \mathrm{nM}$ for blood samples and $24 \mathrm{nM}$ for wastewater samples). They assumed that the novel synthetic route they proposed could pave the way towards the development of covalent organic frameworks to be used in metal removal applications, environmental monitoring, and biomedical sensing.
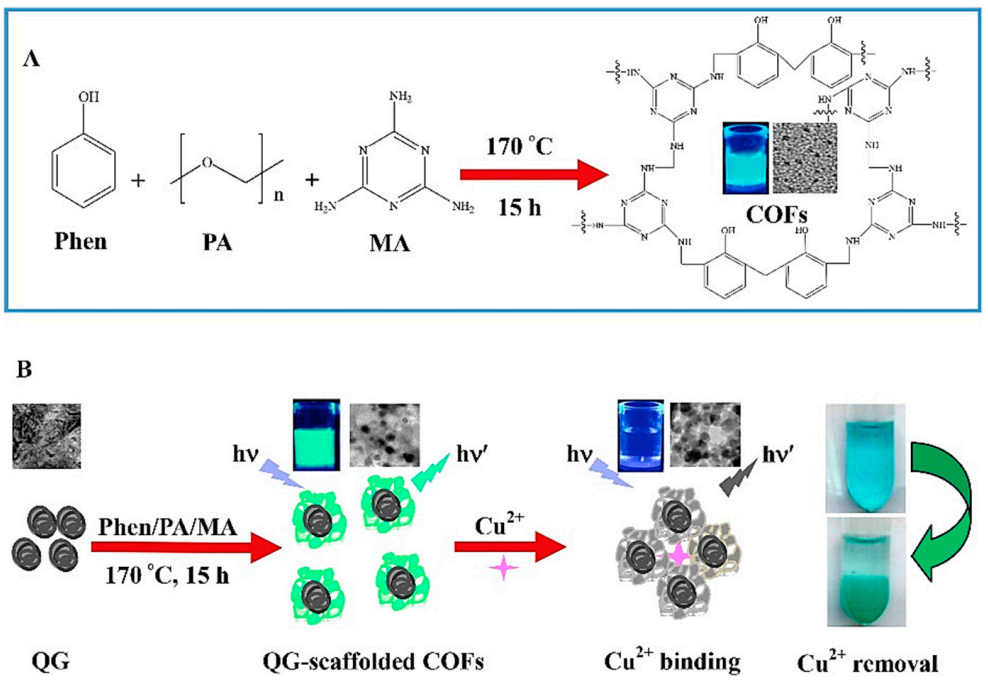

Figure 9. Schematic illustration of (A) the covalent polymerization reaction among melaminealdehyde and phenol-aldehyde to yield COFs. (B) The fabrication and procedure of metal-free QG-scaffolded COFs by the COFs covalent reaction system with QG scaffolds, yielding the products with bright green fluorescence that could be quenched by $\mathrm{Cu}^{2+}$ ions and for the $\mathrm{Cu}^{2+}$ removal (Reprinted with permission from Cai Y., Jiang Y., Feng L., Hua Y., Liu H., Fan C., Yin M., Li S., Lv X., Wang H., Anal Chim Acta, 2019; 1057, 88-97 [123]. Copyright (2019) Elsevier). 
The following year, Li and his team (2020) [124] prepared, through the solvothermal method, a magnetic $\mathrm{Fe}_{3} \mathrm{O}_{4}$-MOF-COF composite material for the selective adsorption of $\mathrm{Cu}^{2+}$ ions. The composite material showed fast separation, enhanced stability, and high adsorption capacity $(37.29 \mathrm{mg} / \mathrm{g})$ towards $\mathrm{Cu}^{2+}$ ions. $\mathrm{Li}$ et al. proposed that the COF addition in the composite material improved the $\mathrm{Cu}^{2+}$ adsorption capacity. As a result, the prepared novel $\mathrm{Fe}_{3} \mathrm{O}_{4}$-MOF-COF material could be utilized for the rapid and sensitive detection and adsorption of $\mathrm{Cu}^{2+}$ ions.

In 2021, Liu et al. [125] utilized a facile and effective reaction process, in order to develop an adenine-grafted COF to be used for the adsorption of $\mathrm{Ag}^{+}$ions. Due to the coordination between $\mathrm{Ag}^{+}$ions and adenine groups, the moderate pore structure, and the good surface area, the as-synthesized covalent organic framework showed a high $\mathrm{Ag}^{+}$ selectivity and adsorption capacity $(40 \mathrm{mg} / \mathrm{L})$, as well as good recyclability. The authors concluded that the proposed adenine-grafted COF could provide a novel prospect for the utilization of such COF materials in water purification and environmental restoration. Moreover, the derived Ag-COF material could be used for antimicrobial applications since it is well-known that silver is an excellent antimicrobial agent.

Table 2. COFs' adsorption performance towards several heavy metal ions and radionuclides.

\begin{tabular}{|c|c|c|c|}
\hline Adsorbents & Adsorbates & $\begin{array}{l}\text { Adsorption } \\
\text { Capacity }\end{array}$ & References \\
\hline TPB-DMTP-COF & $\mathrm{Hg}^{2+}$ & $8.5 \mu \mathrm{g} / \mathrm{L}$ & [76] \\
\hline 2D COF & $\begin{array}{l}\mathrm{Hg}^{0} \\
\mathrm{Hg}^{2+}\end{array}$ & $\begin{array}{c}863 \mathrm{mg} / \mathrm{g} \\
1350 \mathrm{mg} / \mathrm{g}\end{array}$ & [77] \\
\hline$\gamma-\mathrm{Fe}_{2} \mathrm{O}_{3} @ \mathrm{CTF}-1$ & $\mathrm{Hg}^{2+}$ & $165.8 \mathrm{mg} / \mathrm{g}$ & [78] \\
\hline SCTN-1 & $\begin{array}{l}\mathrm{Hg}^{0} \\
\mathrm{Hg}^{2+}\end{array}$ & $\begin{array}{c}813 \mathrm{mg} / \mathrm{g} \\
1253 \mathrm{mg} / \mathrm{g}\end{array}$ & [80] \\
\hline AgNPs@COF & $\mathrm{Hg}^{2+}$ & $113 \mathrm{mg} / \mathrm{g}$ & [81] \\
\hline $\mathrm{COF}_{-} \mathrm{SO}_{3}^{-}$ & $\mathrm{Hg}^{2+}$ & $1299 \mathrm{mg} / \mathrm{g}$ & [83] \\
\hline Metal-free COF & $\mathrm{Hg}^{2+}$ & $98.42 \mathrm{mg} / \mathrm{g}$ & [84] \\
\hline $\mathrm{SH}-\mathrm{COF}$ & $\mathrm{Hg}^{2+}$ & $1283 \mathrm{mg} / \mathrm{g}$ & [85] \\
\hline $\begin{array}{l}\text { COF-TP } \\
\text { COF-TE }\end{array}$ & $\mathrm{Pb}^{2+}$ & $\begin{array}{c}140 \mathrm{mg} / \mathrm{g} \\
185.7 \mathrm{mg} / \mathrm{g}\end{array}$ & [26] \\
\hline COF-SH & $\mathrm{Pb}^{2+}$ & $239 \mathrm{mg} / \mathrm{g}$ & [95] \\
\hline $\begin{array}{c}\text { Guanidium-based } \\
\mathrm{COF}\end{array}$ & $\mathrm{Cr}^{6+}$ & $90-200 \mathrm{mg} / \mathrm{g}$ & [96] \\
\hline Dual-pore COF & $\mathrm{Cr}^{6+}$ & $384 \mathrm{mg} / \mathrm{g}$ & [97] \\
\hline Magnetic COF & $\mathrm{Cr}^{6+}$ & $245.45 \mathrm{mg} / \mathrm{g}$ & [98] \\
\hline $\begin{array}{l}\text { COF1 } \\
\text { COF2 }\end{array}$ & $\mathrm{Cr}^{6+}$ & $\begin{array}{l}462.96 \mathrm{mg} / \mathrm{g} \\
649.35 \mathrm{mg} / \mathrm{g}\end{array}$ & [99] \\
\hline$\gamma-\mathrm{Fe}_{2} \mathrm{O}_{3} @ \mathrm{CTF}-1$ & $\begin{array}{l}\mathrm{As}^{3+} \\
\mathrm{As}^{5+}\end{array}$ & $\begin{array}{l}198 \mathrm{mg} / \mathrm{g} \\
102.3 \mathrm{mg} / \mathrm{g}\end{array}$ & [78] \\
\hline EB-COF:Br & $\mathrm{As}^{5+}$ & $5.1-53.1 \mathrm{mg} / \mathrm{g}$ & [103] \\
\hline $\mathrm{Fe}^{0} / \mathrm{COF}$ & $\mathrm{As}^{3+}$ & $135.78 \mathrm{mg} / \mathrm{g}$ & [104] \\
\hline Heteropore $\mathrm{COF}$ & $\mathrm{Cd}^{2+}$ & $116 \mathrm{mg} / \mathrm{g}$ & [108] \\
\hline N-riched COF & $\mathrm{Cd}^{2+}$ & $396 \mathrm{mg} / \mathrm{g}$ & [105] \\
\hline Heteropore $\mathrm{COF}$ & $\mathrm{I}_{2}$ & $4810 \mathrm{mg} / \mathrm{g}$ & [110] \\
\hline $\mathrm{H}_{\mathrm{C}} \mathrm{OF}$ & $I_{2}$ vapor & $2900 \mathrm{mg} / \mathrm{g}$ & [111] \\
\hline $\mathrm{N}$-riched $\mathrm{COF}$ & $\mathrm{I}_{2}$ & $5.43 \mathrm{~g} / \mathrm{g}$ & [113] \\
\hline COF@cotton fiber & $\mathrm{I}_{2}$ & $533.9 \mathrm{mg} / \mathrm{g}$ & [114] \\
\hline Mesoporous N-COF & $\mathrm{I}_{2}$ & $988.17 \mathrm{mg} / \mathrm{g}$ & [115] \\
\hline HBI-COF & $\mathrm{U}^{6+}$ & $81 \mathrm{mg} / \mathrm{g}$ & [116] \\
\hline AO-COF & $\mathrm{U}^{6+}$ & $68 \mathrm{mg} / \mathrm{g}$ & [117] \\
\hline PAF-1- $\mathrm{CH}_{2}-\mathrm{AO}$ & U6+ & $300 \mathrm{mg} / \mathrm{g}$ & [118] \\
\hline GS-COF & $\mathrm{U}^{6+}$ & $144.2 \mathrm{mg} / \mathrm{g}$ & [119] \\
\hline COF-TpPa & $\mathrm{U}^{6+}$ & $152 \mathrm{mg} / \mathrm{g}$ & [120] \\
\hline $\mathrm{Fe}_{3} \mathrm{O}_{4}$-MOF-COF & $\mathrm{Cu}^{2}+$ & $37.29 \mathrm{mg} / \mathrm{g}$ & [124] \\
\hline Adenine-grafted $\mathrm{COF}$ & $\mathrm{Ag}^{+}$ & $40 \mathrm{mg} / \mathrm{L}$ & [125] \\
\hline
\end{tabular}




\section{Comparison of Covalent Organic Frameworks with the Competitive Systems}

Covalent organic frameworks are an emerging class of functional materials. Due to their functionality and potential of bearing a wealth of side groups, they have found applications, such as adsorption, catalysis, sensing, electronics, and energy storage. Their directly competitive systems are the metal-organic frameworks, graphene oxide, the activated carbons, and the zeolites. For instance, metal organic frameworks (MOFs) constitute versatile materials, utilized in different fields, due to high surface area and adsorption capacity $[8,126]$. In spite of applicability, MOFs face a number of disadvantages, such as ions leakage, low stability, and low conductivity [5]. As a consequence, it is necessary to continuously develop alternative advanced materials, in order to achieve efficient and high-capacity adsorption.

Compared to other materials, COFs possess unique properties, such as high adsorption capacity (Table 3), low density, high specific surface area (for 2D COFs is 711-2160 $\mathrm{m}^{2} / \mathrm{g}$ and for 3D COFs is $1360-4210 \mathrm{~m}^{2} / \mathrm{g}$ ), tunable, ordered, and stable structure, exceptional physical, chemical stability and pore structure, modularity, low mass densities, facile functional design, as well as luminous characteristics in some cases, after the integration of luminescent units into COFs' skeleton $[7,8,24,25,127,128]$. The topological frameworks of the COFs result in their exceptional porous structure, while porosity and crystallinity constitute the main attributes affecting the quality of COFs [24].

The outstanding stability of COFs is ascribed to the high-energy linkage $(50-110 \mathrm{kcal} / \mathrm{mol})$, as well as to the strong intermolecular force, due to the nodes-layers interaction, which prevents the collapse of the crystallography even at severe conditions [25]. The majority of COFs exhibit moderate thermal stability; thus, their stability in aqueous and acidic/alkaline solutions retains a crucial drawback for some types of COFs (e.g., Boron-based), precluding their utilization in water treatment applications. Worldwide, researchers implement various strategies, in order to refine the structural stability of COFs. Some of these strategies include linkage conversion [24,47], linkers' modifications [24,45], and blending [24,120]. In addition, the softened force of covalent bonds between layers enhances the entire connection structure for 3D COFs, due to the resonance effect of long-pair oxygen [25,68].

The aforementioned advantages along with the development of stable COFs in water medium and even in harsh conditions have resulted in the extension of COFs' application from gas storage to other fields, while their environmental application potentials are gradually noticed and highly valued $[29,38,83,87,129]$.

In addition, they consist of light elements only, $\mathrm{C}, \mathrm{Si}, \mathrm{O}, \mathrm{B}$, and $\mathrm{N}$, while no metals are required for the formation of COFs, which makes them appealing in terms of biocompatibility and low production cost. However, in contrast with their competitors, no COF has been commercially available until now. Furthermore, very high absorption values have been reported for MOFs, composite materials based on MOFs, zeolites, and functionalized graphene oxide surfaces [130-133].

Table 3. Summary of the values for lead and mercury adsorption between three main classes of materials.

\begin{tabular}{|c|c|c|c|c|c|c|}
\hline \multirow{3}{*}{$\begin{array}{c}\mathrm{Pb}(\mathrm{II}) \\
\text { adsorption capacity } \\
\mathrm{Hg}(\mathrm{II}) \\
\text { adsorption capacity }\end{array}$} & \multirow{2}{*}{$\begin{array}{c}\text { COF } \\
185.7 \mathrm{mg} / \mathrm{g} \\
{[25,26]}\end{array}$} & \multicolumn{2}{|c|}{ ZEOLITES } & \multicolumn{2}{|c|}{ MOF } & \multirow{2}{*}{$\begin{array}{c}\text { GO } \\
204-479 \mathrm{mg} / \mathrm{g} \\
{[133]}\end{array}$} \\
\hline & & $\begin{array}{l}14 \mathrm{mg} / \mathrm{g} \\
{[134,135]}\end{array}$ & $\begin{array}{c}1348.42 \mathrm{mg} / \mathrm{g} \\
\text { [132] }\end{array}$ & $\begin{array}{c}23.46 \mathrm{mg} / \mathrm{g} \\
{[136]}\end{array}$ & $\begin{array}{c}862.44 \mathrm{mg} / \mathrm{g} \\
{[130]}\end{array}$ & \\
\hline & $\begin{array}{c}4395 \mathrm{mg} / \mathrm{g} \\
{[25,82]}\end{array}$ & $8.0 \mu$ & /g [137] & $\begin{array}{c}718.1 \mathrm{mg} / \mathrm{g} \\
\text { [41] }\end{array}$ & $\begin{array}{c}905.5 \mathrm{mg} / \mathrm{g} \\
{[131]}\end{array}$ & $\begin{array}{c}526.32 \mathrm{mg} / \mathrm{g} \\
{[138]}\end{array}$ \\
\hline
\end{tabular}

\section{Perspectives on the Large-Scale Industrial Applications-Room for Improvement}

For a material that can be applied in real-life applications regarding the removal of toxic metals from aquatic environments, the ease of preparation, low cost, processability, and recyclability are of paramount importance. In general, the yields of condensation reactions for the synthesis of covalent organic networks are particularly high. As an example, an imine-based COF reported by Huang et al. [41] was synthesized with a yield 
of $84 \%$, while Bourlinos et al. reported a yield of $90 \%$ for the same product [139]. Therefore, the presence of by-products is minimized, and the materials can be synthesized on a large, industrial scale. The only drawback is that, for certain materials, a bespoke ligand is required, hence more delicate organic synthesis methods with higher costs and lower yields need to be employed. Zhao et al. summarized the perspective on the industrial applications of COFs [140]. The review covered aspects such as the continuous flow synthesis by utilizing microfluidic devices, catalysis, carbon dioxide capture, and energy storage applications. From the different systems that we have already discussed, the imine-based frameworks appear to be the most promising candidates for industrial-level production and applications. Karak et al. [141] demonstrated methodologies to synthesize covalent organic frameworks on a large scale. The use of certain additives such as $\mathrm{p}$ toluenesulfonic acid was found to be critical for the industrial applications of the derivatives. For a large-scale application of a material, a certain control on the morphology, size, and shape is necessary. The growth mechanism and reaction parameters for their synthesis were studied in detail by Huang's group [142]. They found that initial precipitates of irregular nanoparticles are produced in the initial stages of the reaction, and subsequently, the nanoparticles evolve to microspheres and finally to nanofibers with a simultaneous amorphous-to-crystalline change. An extruder can also be used to produce kg per hour of COFs for a continuous synthesis process, and this appears as a very promising step for scaled-up synthetic pathways. They have also developed a liquid-assisted grinding (LAG) method [31] and synthesized crystalline COFs. The reaction took place at a faster rate and in high yield by optimizing the reaction conditions [143].

A drawback is that mechanochemically synthesized COFs do not have high crystallinity and porosity. Furthermore, kinetic trapping in certain morphologies is leading to limited topologies and lack of sufficient understanding on the growth mechanisms [144]. This kinetic trapping of amorphous structures can be overcome through effective catalysts for nucleation inhibition and hence increased crystallinity.

\section{Biocompatibility of COFs: Are There Any Dangers/Drawbacks When Using Them in Aquatic Environments?}

The emphasis of this review was placed on the detection and the adsorption as well as the extraction of heavy metals with a variety of COFs in different environments. The physicochemical properties, surface area, stability, and modularity are a few of the positive aspects that the COFs provide for these applications. A plausible point of controversy exists and the question that arises is if in their purely organic components, there is a possibility of noxious substances constituting and decomposing from the COFs in the biological systems, in this way refuting their utility to deliver environmentally friendly applications.

COFs are designed in precision from chosen initial molecules and are constructed from synthetic routes that are highly controllable, as referred to before. The selection of biocompatible core and linkages for their production is the primary and necessary step to ensure the biosafety of the networks. They are composed from lightweight elements that are abundant in nature, such as $\mathrm{C}, \mathrm{O}, \mathrm{N}$, and $\mathrm{B}$, and one of their assets is the lack of inorganic substances composing their frameworks. As metal-free materials, they also reduce the levels of toxicity in comparison to the heavy metal-involved nanomaterials and other composites [145]. Then, a top-down approach is needed to obtain COFs at the nanoscale, as the size determines its reactivity, its cellular uptake, distribution, cytotoxicity, and excretion from the human body [146]. Any difficulty of the COFs dispersion in aqueous solutions is addressed by functionalization with hydrophilic groups or encapsulation with other organic derivatives. A restriction that must be taken into consideration is that some of the COFs are unstable in harsh environments. The materials must be tested prior to their incorporation in environmental applications, in highly acidic and alkaline environments, as, for example, the $\mathrm{pH}$ of wastewater is not neutral. Their recyclability is successful, but as the COFs sector is still in its infancy, there is a lot to anticipate in the next years. Even though there are studies proving their efficiency in different applications, we did not find a dedicated research of the COFs' hazardous risks in aqueous environments. On the other 
hand, biosafety is referred to in the biomedical area [147]. Recently, appropriate COFs were developed for pre-treatment of chlorinated drinking water [148], for water treatment [149], for separation membranes [150], adsorption [151], and extraction of organic substances, among all [152,153]. Furthermore, biocompatible COFs for biomedicine [154,155], cancer diagnosis, and treatment in vitro and in vivo (rats and human serums) have been reported [156-158].

Herein, we will only report an example of applicable COFs for photothermal therapy, where with further modification and encapsulation with PEG of their 2D COF, biosafety was ensured in vivo (mice) and the framework was metabolized $24 \mathrm{~h}$ after injection. In this last section, we have defined what was already achieved and what remains to be for the application of COFs nanoplatforms in aqueous environments.

\section{Conclusions}

In this critical review, we discussed the applications of covalent organic frameworks for the removal of heavy metals from aquatic environments. Furthermore, we presented a comparison with their main competitive systems (zeolites and metal-organic frameworks), regarding their adsorption ability towards heavy metals. The COFs' adsorption capacity is comparable to that of zeolites and MOFs. The ability of the COFs to bear a wealth of functional binding groups and to tune their porous structure is their main advantage. Very high values have been reported for the removal of several heavy metals, and coupled with their biocompatibility, this makes them very promising candidates for large-scale industrial applications when certain improvements in the mechanistic study of their growth are made.

Author Contributions: All authors have equally contributed. All authors have read and agreed to the published version of the manuscript.

Funding: P.D. and P.B. would like to acknowledge the Hellenic Foundation for Research and Innovation and the General Secretariat for Research and Technology for grant number 1468 (PLASCAT). T.S. acknowledges the financial support from the European Research Council (ERC) via Consolidator Grant (818615-MIX2FIX) as well as from the Hellenic Foundation for Research and Innovation (H.F.R.I.) under the "First Call for H.F.R.I. Research Projects to support Faculty members and Researchers and the procurement of high-cost research equipment grant" (Project Number: 1027).

Institutional Review Board Statement: Not applicable.

Informed Consent Statement: Not applicable.

Data Availability Statement: Not applicable.

Conflicts of Interest: The authors declare no conflict of interest.

\section{References}

1. Qiao, L.; Li, S.; Li, Y.; Liu, Y.; Du, K. Fabrication of superporous cellulose beads via enhanced inner cross-linked linkages for high efficient adsorption of heavy metal ions. J. Clean. Prod. 2020, 253, 120017. [CrossRef]

2. Hokkanen, S.; Bhatnagar, A.; Sillanpää, M. A review on modification methods to cellulose-based adsorbents to improve adsorption capacity. Water Res. 2016, 91, 156-173. [CrossRef] [PubMed]

3. Zhang, Z.; Chen, K.; Zhao, Q.; Huang, M.; Quyang, X. Comparative adsorption of heavy metal ions in wastewater on monolayer molybdenum disulfide. Green Energy Environ. 2020, in press. [CrossRef]

4. Wang, W.; Fan, X.; Huang, C.; Zheng, H.; Chen, Z.; Fan, B.; Xu, C. Monitoring and comparison analysis of heavy metals in the five great lakes in Jiangsu Province. J. Lake SC 2016, 28, 494-501. [CrossRef]

5. Lin, Z.; Li, J.; Luan, Y.; Dai, W. Application of algae for heavy metal adsorption: A 20-year meta-analysis. Ecotoxicol. Environ. Saf. 2020, 190, 110089. [CrossRef] [PubMed]

6. Islam, M.S.; Ahmed, M.K.; Raknuzzaman, M.; Habibullah Al-Mamun, M.; Islam, M.K. Heavy metal pollution in surface water and sediment: A preliminary assessment of an urban river in a developing country. Ecol. Indicat. 2015, 48, 282-291. [CrossRef]

7. Wang, H.; Wang, T.; Ma, R.; Wu, K.; Li, H.; Feng, B.; Li, C.; Shen, Y. Facile synthesis of sulfonated covalent organic framework for the adsorption of heavy metal ions. J. Taiwan Inst. Chem. Eng. 2020, 112, 122-129. [CrossRef]

8. Bagheri, A.R.; Aramesh, N.; Sher, F.; Bilal, M. Covalent organic frameworks as robust materials for mitigation of environmental pollutants. Chemosphere 2021, 270, 129523. [CrossRef] 
9. d'Halluin, M.; Ru-Barrull, J.; Bretel, G.; Labrugere, C.; Le Grognec, E.; Felpin, F.X. Chemically modified cellulose filter paper for heavy metal remediation in water. ACS Sustain. Chem. Eng. 2017, 5, 1965-1973. [CrossRef]

10. Shih, Y.J.; Chien, S.K.; Jhang, S.R.; Lin, Y.C. Chemical leaching, precipitation and solvent extraction for sequential separation of valuable metals in cathode material of spent lithium ion batteries. J. Taiwan Inst. Chem. Eng. 2019, 100, 151-159. [CrossRef]

11. Shu, J.; Wu, H.; Chen, M.; Peng, H.; Li, B.; Liu, R.; Liu, Z.; Wang, B.; Huang, T.; Hu, Z. Fractional removal of manganese and ammonia nitrogen from electrolytic metal manganese residue leachate using carbonate and struvite precipitation. Water Res. 2019, 153, 229-238. [CrossRef]

12. Shi, X.; Wang, R.; Xiao, A.; Jia, T.; Sun, S.P.; Wang, Y. Layer-by-layer synthesis of covalent organic frameworks on porous substrates for fast molecular separations. ACS Appl. Nano Mater. 2018, 1, 6320-6326. [CrossRef]

13. Walekar, L.; Dutta, T.; Kumar, P.; Ok, Y.S.; Pawar, S.; Deep, A.; Kim, K.H. Functionalized fluorescent nanomaterials for sensing pollutants in the environment: A critical review. Trac. Trends Anal. Chem. 2017, 97, 458-467. [CrossRef]

14. Zou, Q.; Zhang, Z.; Li, H.; Pei, W.; Ding, M.; Xie, Z.; Huo, Y.; Li, H. Synergistic removal of organic pollutant and metal ions in photocatalysis-membrane distillation system. Appl. Catal. B 2020, 118463. [CrossRef]

15. Peydayesh, M.; Bolisetty, S.; Mohammadi, T.; Mezzenga, R. Assessing the binding performance of amyloid-carbon membranes toward heavy metal ions. Langmuir 2019, 35, 4161-4170. [CrossRef] [PubMed]

16. $\mathrm{Hu}, \mathrm{J} . ; \mathrm{Li}$, J.; Cui, J.; An, W.; Liu, L.; Liang, Y.; Cui, W. Surface oxygen vacancies enriched FeOOH/ $\mathrm{Bi}_{2} \mathrm{MoO}_{6}$ photocatalysis-Fenton synergy degradation of organic pollutants. J. Hazard. Mater. 2020, 121399. [CrossRef]

17. Ansari, S. Combination of molecularly imprinted polymers and carbon nanomaterials as a versatile biosensing tool in sample analysis: Recent applications and challenges. Trac. Trends Anal. Chem. 2017, 93, 134-151. [CrossRef]

18. Acharya, J.; Kumar, U.; Rafi, P.M. Removal of heavy metal ions from wastewater by chemically modified agricultural waste material as potential adsorbent-a review. Int. J. Curr. Eng. Technol. 2018, 8, 526-530. [CrossRef]

19. Abdel Maksoud, M.I.A.; Elgarahy, A.M.; Farrell, C.; Al-Muhtaseb, A.H.; Rooney, D.W.; Osman, A.I. Insight on water remediation application using magnetic nanomaterials and biosorbents. Coord. Chem. Rev. 2020, 403, 213096. [CrossRef]

20. Zhao, G.; Huang, X.; Tang, Z.; Huang, Q.; Niu, F.; Wang, X. Polymer-based nanocomposites for heavy metal ions removal from aqueous solution: A review. Polym. Chem. 2018, 9, 3562-3582. [CrossRef]

21. He, X.; Qiu, X.; Hu, C.; Liu, Y. Treatment of heavy metal ions in wastewater using layered double hydroxides: A review. J. Dispers. Sci. Technol. 2018, 39, 792-801. [CrossRef]

22. Meteku, B.E.; Huang, J.; Zeng, J.; Subhan, F.; Feng, F.; Zhang, Y.; Qiu, Z.; Aslam, S.; Li, G.; Yan, Z. Magnetic metal-organic framework composites for environmental monitoring and remediation. Coord. Chem. Rev. 2020, 413, 213261. [CrossRef]

23. Xu, J.; Cao, Z.; Zhang, Y.; Yuan, Z.; Lou, Z.; Xu, X.; Wang, X. A review of functionalized carbon nanotubes and graphene for heavy metal adsorption from water: Preparation, application, and mechanism. Chemosphere 2018, 195, 351-364. [CrossRef]

24. Zhou, T.; Ding, L.; Che, G.; Jiang, W.; Sang, L. Recent advances and trends of molecularly imprinted polymers for specific recognition in aqueous matrix: Preparation and application in sample pretreatment. Trac. Trends Anal. Chem. 2019, 114, 11-28. [CrossRef]

25. Zhang, N.; Ishag, A.; Li, Y.; Wang, H.; Guo, H.; Mei, P.; Meng, Q.; Sun, Y. Recent investigations and progress in environmental remediation by using covalent organic framework-based adsorption method: A review. J. Clean. Prod. 2020, 277, 123360. [CrossRef]

26. Li, G.; Ye, J.; Fang, Q.; Liu, F. Amide-based covalent organic frameworks materials for efficient and recyclable removal of heavy metal lead (II). Chem. Eng. J. 2019, 370, 822-830. [CrossRef]

27. Wang, J.; Zhuang, S. Covalent organic frameworks (COFs) for environmental applications. Coord. Chem. Rev. 2019, 400, 213046. [CrossRef]

28. Huang, N.; Wang, P.; Jiang, D. Covalent organic frameworks: A materials platform for structural and functional designs. Nat. Rev. Mater. 2016, 1, 1-19. [CrossRef]

29. Geng, K.; Arumugam, V.; Xu, H.; Gao, Y.; Jiang, D. Covalent organic frameworks: Polymer chemistry and functional design. Prog. Polym. Sci. 2020, 108, 101288. [CrossRef]

30. Baldwin, L.A.; Crowe, J.W.; Pyles, D.A.; McGracier, P.L. Metalation of a mesoporous three-dimensional covalent organic framework. J. Am. Chem. Soc. 2016, 138, 15134-15137. [CrossRef]

31. Cao, S.; Li, B.; Zhu, R.; Pang, H. Design and synthesis of covalent organic frameworks towards energy and environment fields. Chem. Eng. J. 2019, 355, 602-623. [CrossRef]

32. Dey, K.; Pal, M.; Rout, K.C.; Kunjattu, H.S.; Das, A.; Mukherjee, R.; Kharul, U.K.; Banerjee, R. Selective molecular separation by interfacially crystallized covalent organic framework thin films. J. Am. Chem. Soc. 2017, 139, 13083-13091. [CrossRef] [PubMed]

33. Wang, X.; Han, X.; Zhang, J.; Wu, X.; Liu, Y.; Cui, Y. Homochiral 2D porous covalent organic frameworks for heterogeneous asymmetric catalysis. J. Am. Chem. Soc. 2016, 138, 12332-12335. [CrossRef]

34. You, J.; Zhao, Y.; Wang, L.; Bao, W. Recent developments in the photocatalytic applications of covalent organic frameworks: A review. J. Clean. Prod. 2021, 291, 125822. [CrossRef]

35. Guan, X.; Ma, Y.; Li, H.; Yusran, Y.; Xue, M.; Fang, Q.; Yan, Y.; Valtchev, V.; Qiu, S. Fast, ambient temperature and pressure ionothermal synthesis of three-dimensional covalent organic frameworks. J. Am. Chem. Soc. 2018, 140, 4494-4498. [CrossRef] [PubMed] 
36. Bisbey, R.P.; Dichtel, W.R. Covalent organic frameworks as a platform for multidimensional polymerization. ACS Cent. Sci. 2017, 3, 533-543. [CrossRef]

37. Kandambeth, S.; Dey, K.; Banerjee, R. Covalent organic frameworks: Chemistry beyond the structure. J. Am. Chem. Soc. 2018, 141, 1807-1822. [CrossRef]

38. Lohse, M.S.; Bein, T. Covalent organic frameworks: Structures, synthesis, and applications. Adv. Funct. Mater. 2018, $28,1705553$. [CrossRef]

39. Medina, D.D.; Rotter, J.M.; Hu, Y.; Dogru, M.; Werner, V.; Auras, F.; Markiewicz, J.T.; Knochel, P.; Bein, T. Room temperature synthesis of covalent-organic framework films through vapor-assisted conversion. J. Am. Chem. Soc. 2015, 137, 1016-1019. [CrossRef]

40. Jin, E.; Li, J.; Geng, K.; Jiang, Q.; Xu, H.; Xu, Q.; Jiang, D. Designed synthesis of stable light-emitting two-dimensional sp ${ }^{2}$ carbon-conjugated covalent organic frameworks. Nat. Commun. 2018, 9, 4143. [CrossRef]

41. Huang, N.; Zhai, L.; Xu, H.; Jiang, D. Stable covalent organic frameworks for exceptional mercury removal from aqueous solutions. J. Am. Chem. Soc. 2017, 139, 2428-2434. [CrossRef] [PubMed]

42. Waller, P.J.; Gándara, F.; Yaghi, O.M. Chemistry of covalent organic frameworks. ACC Chem. Res. 2015, 48, 3053-3063. [CrossRef]

43. Lyu, H.; Diercks, C.S.; Zhu, C.; Yaghi, O.M. Porous crystalline olefin-linked covalent organic frameworks. J. Am. Chem. Soc. 2019, 141, 6848-6852. [CrossRef]

44. Li, X.; Zhan, C.; Cai, S.; Lei, X.; Altoe, V.; Hong, F.; Urban, J.J.; Ciston, J.; Chan, E.M.; Liu, Y. Facile transformation of imine covalent organic frameworks into ultrastable crystalline porous aromatic frameworks. Nat. Commun. 2018, 9, 2998. [CrossRef]

45. Du, Y.; Yang, H.; Whiteley, J.M.; Wa, S.; Jin, Y.; Lee, S.H.; Zhang, W. Ionic covalent organic frameworks with spiroborate linkage. Angew. Chem. Int. Ed. 2016, 55, 1737-1741. [CrossRef] [PubMed]

46. Haase, F.; Troschke, E.; Savasci, G.; Banerjee, T.; Duppel, V.; Dörfler, S.; Grundei, M.M.J.; Burow, A.M.; Ochsenfeld, C.; Kaskel, S.; et al. Topochemical conversion of an imine- into a thiazole-linked covalent organic framework enabling real structure analysis. Nat. Commun. 2018, 9, 2600. [CrossRef] [PubMed]

47. Chen, X.; Addicoat, M.; Jin, E.; Zhai, L.; Xu, H.; Huang, N.; Guo, Z.; Lili, L.; Irle, S.; Jiang, D. Locking covalent organic frameworks with hydrogen bonds: General and remarkable effects on crystalline structure, physical properties, and photochemical activity. $J$. Am. Chem. Soc. 2015, 137, 3241-3247. [CrossRef]

48. Xu, H.; Gao, J.; Jiang, D. Stable, crystalline, porous, covalent organic frameworks as a platform for chiral organocatalysts. Nat. Chem. 2015, 7, 905-912. [CrossRef] [PubMed]

49. Fang, Q.; Gu, S.; Zheng, J.; Zhuang, Z.; Qiu, S.; Yan, Y. 3D microporous base-functionalized covalent organic frameworks for size-selective catalysis. Angew. Chem. Int. Ed. 2014, 53, 2878-2882. [CrossRef] [PubMed]

50. Jin, E.; Geng, K.; Lee, K.H.; Jiang, W.; Li, J.; Jiang, Q.; Irle, S.; Jiang, D. Topology-templated synthesis of crystalline porous covalent organic frameworks. Angew. Chem. 2020, 59, 12162-12169. [CrossRef] [PubMed]

51. Bi, S.; Yang, C.; Zhang, W.; Xu, J.; Liu, L.; Wu, D.; Wang, X.; Han, Y.; Liang, Q.; Zhang, F. Two-dimensional semiconducting covalent organic frameworks via condensation at arylmethyl carbon atoms. Nat. Commun. 2019, 10, 2467. [CrossRef] [PubMed]

52. Acharjya, A.; Pachfule, P.; Roeser, J.; Schmitt, F.J.; Thomas, A. Vinylene-linked covalent organic frameworks by base-catalyzed aldol condensation. Angew. Chem. Int. Ed. 2019, 58, 14865-14870. [CrossRef] [PubMed]

53. Jin, E.; Asada, M.; Xu, Q.; Dalapati, S.; Addicoat, M.A.; Brady, M.A.; Xu, H.; Nakamura, T.; Heine, T.; Chen, Q.; et al. Twodimensional $\mathrm{sp}^{2}$ carbon-conjugated covalent organic frameworks. Science 2017, 357, 673-676. [CrossRef] [PubMed]

54. Zhuang, X.; Zhao, W.; Zhang, F.; Cao, Y.; Liu, F.; Bi, S.; Feng, X. A two-dimensional conjugated polymer framework with fully $\mathrm{sp}^{2}$-bonded carbon skeleton. Polym. Chem. 2016, 7, 4176-4181. [CrossRef]

55. Zhang, B.; Wei, M.; Mao, H.; Pei, X.; Alshmimri, S.A.; Reimer, J.A.; Yaghi, O.M. Crystalline dioxin-linked covalent organic frameworks from irreversible reactions. J. Am. Chem. Soc. 2018, 140, 12715-12719. [CrossRef]

56. Waller, P.J.; Lyle, S.J.; Osborn Popp, T.M.; Diercks, C.S.; Reimer, J.A.; Yaghi, O.M. Chemical conversion of linkages in covalent organic frameworks. J. Am. Chem. Soc. 2016, 138, 15519-15522. [CrossRef]

57. Liu, H.; Chu, J.; Yin, Z.; Cai, X.; Zhuang, L.; Deng, H. Covalent organic frameworks linked by amine bonding for concerted electrochemical reduction of $\mathrm{CO}_{2}$. Chem 2018, 4, 1696-1709. [CrossRef]

58. Waller, P.J.; AlFaraj, Y.S.; Diercks, C.S.; Jarenwattananon, N.N.; Yaghi, O.M. Conversion of imine to oxazole and thiazole linkages in covalent organic frameworks. J. Am. Chem. Soc. 2018, 140, 9099-9103. [CrossRef]

59. Mahmood, J.; Ahmad, I.; Jung, M.; Seo, J.M.; Yu, S.Y.; Noh, H.J.; Kim, Y.H.; Shin, H.J.; Baek, J.B. Two-dimensional amine and hydroxy functionalized fused aromatic covalent organic framework. Commun. Chem. 2020, 3. [CrossRef]

60. Segura, J.L.; Mancheño, M.J.; Zamora, F. Covalent organic frameworks based on Schiff-base chemistry: Synthesis, properties and potential applications. Chem. Soc. Rev. 2016, 45, 5635-5671. [CrossRef]

61. Qian, C.; Qi, Q.Y.; Jiang, G.F.; Cui, F.Z.; Tian, Y.; Zhao, X. Toward covalent organic frameworks bearing three different kinds of pores: The strategy for construction and COF-to-COF transformation via heterogeneous linker exchange. J. Am. Chem. Soc. 2017, 139, 6736-6743. [CrossRef] [PubMed]

62. Li, N.; Du, J.; Wu, D.; Liu, J.; Li, N.; Sun, Z.; Li, G.; Wu, Y. Recent advances in facile synthesis and applications of covalent organic framework materials as superior adsorbents in sample pretreatment. Trac. Trends Anal. Chem. 2018, 108, 154-166. [CrossRef]

63. Smith, B.J.; Overholts, A.C.; Hwang, N.; Dichtel, W.R. Insight into the crystallization of amorphous imine-linked polymer networks to 2D covalent organic frameworks. Chem. Commun. 2016, 52, 3690-3693. [CrossRef] 
64. Koo, B.T.; Heden, R.F.; Clancy, P. Nucleation and growth of 2D covalent organic frameworks: Polymerization and crystallization of COF monomers. Phys. Chem. Chem. Phys. 2017, 19, 9745-9754. [CrossRef]

65. Singh, V.; Jang, S.; Vishwakarma, N.K.; Kim, D.P. Intensified synthesis and post-synthetic modification of covalent organic frameworks using a continuous flow of microdroplets technique. NPG Asia Mater. 2018, 10, 456. [CrossRef]

66. Gan, J.S.; Bagheri, A.R.; Aramesh, N.; Gul, I.; Franco, M.; Almulaiky, Y.Q.; Bilal, M. Covalent organic frameworks as emerging host platforms for enzyme immobilization and robust biocatalysis-A review. Int. J. Biol. Macromol. 2021, 167, 502-515. [CrossRef] [PubMed]

67. Jiang, D.; Gao, Y.; Wang, C.H.H.; Ge, R.; Lu, M.; Zhang, J.; Li, Z.; Shao, P. Synthesis of two-dimensional covalent organic frameworks in ionic liquids. Chem. A Eur. J. 2019, 25, 15488-15492. [CrossRef]

68. Kuchenbuch, A.; Giernoth, R. Ionic liquids beyond simple solvents: Glimpses at the state of the art in Organic Chemistry. Chem. Open 2015, 4, 677-681. [CrossRef]

69. Ge, J.; Xiao, J.; Liu, L.; Qiu, L.; Jiang, X. Facile microwave-assisted production of $\mathrm{Fe}_{3} \mathrm{O}_{4}$ decorated porous melamine-based covalent organic framework for highly selective removal of $\mathrm{Hg}^{2+}$. J. Porous Mater. 2016, 23, 791800. [CrossRef]

70. Wei, H.; Chai, S.; Hu, N.; Yang, Z.; Wei, L.; Wang, L. The microwave-assisted solvothermal synthesis of a crystalline twodimensional covalent organic framework with high $\mathrm{CO}_{2}$ capacity. Chem. Commun. 2015, 51, 12178-12181. [CrossRef] [PubMed]

71. Lyu, H.; Gao, B.; He, F.; Ding, C.; Tang, J.; Crittenden, J.C. Ball-milled carbon nanomaterials for energy and environmental applications. ACS Sustain. Chem. Eng. 2017, 5, 9568-9585. [CrossRef]

72. Jadhav, T.; Fang, Y.; Patterson, W.; Liu, C.H.; Hamzehpoo, E.; Perepichka, D.F. 2D Poly(arylene vinylene) covalent organic frameworks via aldol condensation of trimethyltriazine. Angew. Chem. Int. Ed. 2019, 58, 13753-13757. [CrossRef] [PubMed]

73. Velempini, T.; Pillay, K. Sulphur functionalized materials for $\mathrm{Hg}$ (II) adsorption: A review. J. Environ. Chem. Eng. 2019, 7, 103350. [CrossRef]

74. Wu, S.; Uddin, M.A.; Nagano, S.; Ozaki, M.; Sasaoka, E. Fundamental study on decomposition characteristics of mercury compounds over solid powder by temperature-programmed decomposition desorption mass spectrometry. Energy Fuels 2011, 25, 144-153. [CrossRef]

75. Ram, B.; Chauhan, G.S. New spherical nanocellulose and thiol-based adsorbent for rapid and selective removal of mercuric ions. Chem. Eng. J. 2018, 331, 587-596. [CrossRef]

76. Merí-Bofí, L.; Royuela, S.; Zamora, F.; Ruiz-González, M.L.; Segura, J.L.; Muñoz-Olivas, R.; Mancheño, M.J. Thiol grafted imine-based covalent organic frameworks for water remediation through selective removal of $\mathrm{Hg}$ (II). J. Mater. Chem. A 2017, 5, 17973-17981. [CrossRef]

77. Sun, B.; Liu, J.; Cao, A.; Song, W.; Wang, D. Interfacial synthesis of ordered and stable covalent organic frameworks on amino-functionalized carbon nanotubes with enhanced electrochemical performance. Chem. Commun. 2017, 53, 6303-6306. [CrossRef]

78. Leus, K.; Folens, K.; Nicomel, N.R.; Perez, J.P.H.; Filippousi, M.; Meledina, M.; Dirtu, M.M.; Turner, S.; Van Tendeloo, G.; Garcia, Y.; et al. Removal of arsenic and mercury species from water by covalent triazine framework encapsulated $\gamma-\mathrm{Fe}_{2} \mathrm{O}_{3}$ nanoparticles. J. Hazard. Mater. 2018, 353, 312-319. [CrossRef]

79. Fu, Y.; Yu, W.; Zhang, W.; Huang, Q.; Yan, J.; Pan, C.; Yu, G. Sulfur-rich covalent triazine polymer nanospheRes. for environmental mercury removal and detection. Polym. Chem. 2018, 9, 4125-4131. [CrossRef]

80. Mondal, S.; Chatterjee, S.; Mondal, S.; Bhaumik, A. Thioether-functionalized covalent triazine nanospheres: A robust adsorbent for mercury removal. ACS Sustain. Chem. Eng. 2019, 7, 7353-7361. [CrossRef]

81. Wang, L.; Xu, H.; Qiu, Y.; Liu, X.; Huang, W.; Yan, N.; Qu, Z. Utilization of Ag nanoparticles anchored in covalent organic frameworks for mercury removal from acidic waste water. J. Hazard. Mater. 2019, 121824. [CrossRef]

82. He, Y.; Wang, X.; Wang, K.; Wang, L. A triarylamine-based fluorescent covalent organic framework for efficient detection and removal of mercury (II) ion. Dye. Pigm. 2020, 173, 107880. [CrossRef]

83. Tao, Y.; Xiong, X.H.; Xiong, J.B.; Yang, L.X.; Fan, Y.L.; Feng, H.; Luo, F. High-performance removal of mercury ions (II) and mercury vapor by $\mathrm{SO}_{3}{ }^{-}$-anchored covalent organic framework. J. Solid State Chem. 2020, 282, 121126. [CrossRef]

84. Panda, A.; Yang, Y.; Venkateswarlu, S.; Son, Y.; Bae, T.H.; Yoon, M. Highly durable covalent organic framework for the simultaneous ultrasensitive detection and removal of noxious $\mathrm{Hg}^{2+}$. Microporous Mesoporous Mater. 2020, 306, 110399. [CrossRef]

85. Ma, Z.; Liu, F.; Liu, N.; Liu, W.; Tong, M. Facile synthesis of sulfhydryl modified covalent organic frameworks for high efficient $\mathrm{Hg}$ (II) removal from water. J. Hazard. Mater. 2020, 124190. [CrossRef] [PubMed]

86. Yu, Y.; Li, G.; Liu, J.; Yuan, D. A recyclable fluorescent covalent organic framework for exclusive detection and removal of mercury (II). Chem. Eng. J. 2020, 401, 126139. [CrossRef]

87. Awual, M.R. Mesoporous composite material for efficient lead (II) detection and removal from aqueous media. J. Environ. Chem. Eng. 2019, 7, 103124. [CrossRef]

88. Wu, Y.; Pang, H.; Liu, Y.; Wang, X.; Yu, S.; Fu, D.; Chen, J.; Wang, X. Environmental remediation of heavy metal ions by novel-nanomaterials: A review. Environ. Pollut. 2019, 246, 608-620. [CrossRef] [PubMed]

89. Feng, H.; Tang, L.; Tang, J.; Zeng, G.; Dong, H.; Deng, Y.; Wang, L.; Liu, Y.; Ren, X.; Zhou, Y. Cu-doped Fe@Fe $\mathrm{O}_{3}$ core-shell nanoparticle shifted oxygen reduction pathway for high-efficiency arsenic removal in smelting wastewater. Environ. Sci. Nano 2018, 5, 1595-1607. [CrossRef] 
90. Zhu, H.; Yuan, J.; Tan, X.; Zhang, W.; Fang, M.; Wang, X. Efficient removal of $\mathrm{Pb}^{2+}$ by Tb-MOFs: Identifying the adsorption mechanism through experimental and theoretical investigations. Environ. Sci. Nano 2019, 6, 261-272. [CrossRef]

91. Du, Y.; Wang, J.; Zou, Y.; Yao, W.; Hou, J.; Xia, L.; Peng, A.; Alsaedi, A.; Hayat, T.; Wang, X. Synthesis of molybdenum disulfide/reduced graphene oxide composites for effective removal of $\mathrm{Pb}$ (II) from aqueous solutions. Sci. Bull. 2017, 62, 913-922. [CrossRef]

92. Gupta, K.M.; Zhang, K.; Jiang, J. Efficient removal of $\mathrm{Pb}^{2+}$ from aqueous solution by an ionic covalent-organic framework: Molecular simulation study. Ind. Eng. Chem. Res. 2018, 57, 6477-6482. [CrossRef]

93. Zhang, T.; Gao, C.; Huang, W.; Chen, Y.; Wang, Y.; Wang, J. Covalent organic framework as a novel electrochemical platform for highly sensitive and stable detection of lead. Talanta 2018, 188, 578-583. [CrossRef]

94. Xu, W.; Sun, X.; Huang, M.; Pan, X.; Huang, X.; Zhuang, H. Novel covalent organic framework/PVDF ultrafiltration membranes with antifouling and lead removal performance. J. Environ. Manag. 2020, 269, 110758. [CrossRef]

95. Cao, Y.; Yu, X.; Zhu, C.; Zhou, S.; Li, R.; Shi, H.; Miao, S.; Vakil, M.; Wang, W.; Qi, D. Sulfhydryl functionalized covalent organic framework as an efficient adsorbent for selective Pb (II) removal. Phys. Eng. Asp. 2020, 600, 125004. [CrossRef]

96. Jansone-Popova, S.; Moinel, A.; Schott, J.A.; Mahurin, S.M.; Popovs, I.; Veith, G.M.; Moyer, B.A. Guanidinium-based ionic covalent organic framework for rapid and selective removal of toxic $\mathrm{Cr}$ (VI) oxoanions from water. Environ. Sci. Technol. 2018, 53, 878-883. [CrossRef] [PubMed]

97. Cui, F.Z.; Liang, R.R.; Qi, Q.Y.; Jiang, G.F.; Zhao, X. Efficient removal of Cr (VI) from aqueous solutions by a dual-pore covalent organic framework. Adv. Sustain. Syst. 2019, 1800150. [CrossRef]

98. Zhong, X.; Lu, Z.; Liang, W.; Hu, B. The magnetic covalent organic framework as a platform for high-performance extraction of $\mathrm{Cr}$ (VI) and bisphenol a from aqueous solution. J. Hazard. Mater. 2020, 393, 122353. [CrossRef]

99. Zhu, D.; Zhou, S.; Zhou, Z.; Li, R.; Ye, J.; Ziyu, X.; Lan, S.; Zhang, Y.; Miao, S.; Wang, W. Highly efficient and selective removal of $\mathrm{Cr}$ (VI) by covalent organic frameworks: Structure, performance and mechanism. Colloids Surf. A 2020, 600, 124910. [CrossRef]

100. Mukherjee, S.; Thakur, A.K.; Goswami, R.; Mazumder, P.; Taki, K.; Vithanage, M.; Kumar, M. Efficacy of agricultural waste derived biochar for arsenic removal: Tackling water quality in the Indo-Gangetic plain. J. Environ. Manag. 2021, $281,111814$. [CrossRef] [PubMed]

101. Borah, R.; Taki, K.; Gogoi, A.; Da, P.; Kumar, M. Contemporary distribution and impending mobility of arsenic, copper and zinc in a tropical (Brahmaputra) river bed sediment, Assam, India. Ecotoxicol. Environ. Saf. 2018, 161, 769-776. [CrossRef]

102. Kumar, M.; Goswami, R.; Patel, A.K.; Srivastava, M.; Das, N. Scenario, perspectives and mechanism of arsenic and fluoride Co-occurrence in the groundwater: A review. Chemosphere 2020, 249, 126126. [CrossRef]

103. Yang, C.H.; Chang, J.S.; Lee, D.J. Covalent organic framework EB-COF:Br as adsorbent for phosphorus (V) or arsenic (V) removal from nearly neutral waters. Chemosphere 2020, 253, 126736. [CrossRef]

104. Liu, X.; Xu, H.; Wang, L.; Qu, Z.; Yan, N. Surface nano-traps of Fe $\mathrm{F}^{0}$ COFs for arsenic (III) depth removal from wastewater in non-ferrous smelting industry. Chem. Eng. J. 2020, 381, 122559. [CrossRef]

105. Dinari, M.; Hatami, M. Novel N-riched crystalline covalent organic framework as a highly porous adsorbent for effective cadmium removal. J. Environ. Chem. Eng. 2019, 7, 102907. [CrossRef]

106. Nguyen, V.D.; Pham, T.T.; Vranova, V.; Nguyen, H.T.H.; Nguyen, L.T.N.; Vuong, X.T.; Bui, Q.M. Removal of cadmium from aqueous solution using sonochemically modified clinoptilolite: Optimization and modeling. Environ. Technol. Innov. 2020, 20, 101166. [CrossRef]

107. Shafiof Sadatal, M.; Nezamzadeh-Ejhieh, A. A comprehensive study on the removal of Cd (II) from aqueous solution on a novel pentetic acid-clinoptilolite nanoparticles adsorbent: Experimental design, kinetic and thermodynamic aspects. Solid State Sci. 2020, 99, 106071. [CrossRef]

108. Liu, N.; Shi, L.; Han, X.; Qi, Q.Y.; Wu, Z.Q.; Zhao, X. A heteropore covalent organic framework for adsorptive removal of Cd (II) from aqueous solutions with high efficiency. Chin. Chem. Lett. 2020, 31, 386-390. [CrossRef]

109. El-Shahat, M.; Abdelhamid, A.E.; Abdelhameed, R.M. Capture of iodide from wastewater by effective adsorptive membrane synthesized from MIL-125- $\mathrm{NH}_{2}$ and cross-linked chitosan. Carbohydr. Polym. 2020, 231, 115742. [CrossRef]

110. Yin, Z.J.; Xu, S.Q.; Zhan, T.G.; Qi, Q.Y.; Wu, Z.Q.; Zhao, X. Ultrahigh volatile iodine uptake by hollow microspheRes. formed from a heteropore covalent organic framework. Chem. Commun. 2017, 53, 7266-7269. [CrossRef] [PubMed]

111. Lin, Y.; Jiang, X.; Kim, S.T.; Alahakoon, S.B.; Hou, X.; Zhang, Z.; Thomson, C.M.; Smaldone, R.A.; Ke, C. An elastic hydrogenbonded cross-linked organic framework for effective iodine capture in water. J. Am. Chem. Soc. 2017, 139, 7172-7175. [CrossRef]

112. Wang, P.; Xu, Q.; Li, Z.; Jiang, W.; Jiang, Q.; Jiang, D. Exceptional iodine capture in 2D covalent organic frameworks. Adv. Mater. 2018, 30, 1801991. [CrossRef]

113. Guo, X.; Tian, Y.; Zhang, M.; Li, Y.; Wen, R.; Li, X.; Xue, Y.; Ma, L.; Xia, C.; Li, S. Mechanistic insight into hydrogen-bond-controlled crystallinity and adsorption property of covalent organic frameworks from flexible building blocks. Chem. Mater. 2018, 30, 2299-2308. [CrossRef]

114. Li, Y.; Li, Y.; Zhao, Q.; Li, L.; Chen, R.; He, C. Cotton fiber functionalized with 2D covalent organic frameworks for iodine capture. Cellulose 2019, 27, 1517-1529. [CrossRef]

115. Chen, R.; Hu, T.; Li, Y. Stable nitrogen-containing covalent organic framework as porous adsorbent for effective iodine capture from water. React. Funct. Polym. 2021, 159, 104806. [CrossRef] 
116. Li, J.; Suo, L.; Meng, Y.; Li, H. Graph-based fair resource allocation scheme combining interference alignment in femtocell networks. IET Commun. 2015, 9, 211-218. [CrossRef]

117. Bai, C.; Zhang, M.; Li, B.; Zhao, X.; Zhang, S.; Wang, L.; Li, Y.; Zhang, J.; Ma, L.; Li, S. Modifiable diyne-based covalent organic framework: A versatile platform for in situ multipurpose functionalization. RSC Adv. 2016, 6, 39150-39158. [CrossRef]

118. Li, B.; Sun, Q.; Zhang, Y.; Abney, C.W.; Aguila, B.; Lin, W.; Ma, S. Functionalized porous aromatic framework for efficient uranium adsorption from aqueous solutions. ACS Appl. Mater. Interfaces 2017, 9, 12511-12517. [CrossRef] [PubMed]

119. Wen, R.; Li, Y.; Zhang, M.; Guo, X.; Li, X.; Li, X.; Han, J.; Hu, S.; Tan, W.; Ma, L.; et al. Graphene-synergized 2D covalent organic framework for adsorption: A mutual promotion strategy to achieve stabilization and functionalization simultaneously. J. Hazard. Mater. 2018, 358, 273-285. [CrossRef]

120. Li, Z.D.; Zhang, H.Q.; Xiong, X.H.; Luo, F. U (VI) adsorption onto covalent organic frameworks-TpPa-1. J. Solid State Chem. 2019, 277, 484-492. [CrossRef]

121. Zhou, Z.; Zhong, Z.; Cui, K.; Zhuang, Z.; Li, L.; Li, L.; Bi, J.; Yu, Y. A covalent organic framework bearing thioether pendant arms for selective detection and recovery of Au from ultra-low concentration aqueous solution. Chem. Commun. 2018, 54, 9977-9980. [CrossRef]

122. Lu, Q.; Ma, Y.; Li, H.; Guan, X.; Yusran, Y.; Xue, M.; Fang, Q.; Yan, Y.; Qiu, S.; Valtchev, V. Postsynthetic functionalization of three-dimensional covalent organic frameworks for selective extraction of lanthanide ions. Angew. Chem. Int. Ed. 2018, 57, 6042-6048. [CrossRef] [PubMed]

123. Cai, Y.; Jiang, Y.; Feng, L.; Hua, Y.; Liu, H.; Fan, C.; Yin, M.; Li, S.; Lv, X.; Wang, H. Q-graphene-scaffolded covalent organic frameworks as fluorescent probes and sorbents for the fluorimetry and removal of copper ions. Anal. Chim. Acta 2019, 1057, 88-97. [CrossRef]

124. Li, W.T.; Shi, W.; Hu, Z.J.; Yang, T.; Chen, M.L.; Zhao, B.; Wang, J.H. Fabrication of magnetic Fe $\mathrm{O}_{4} @ \mathrm{metal}$ organic framework@covalent organic framework composite and its selective separation of trace copper. Appl. Surf. Sci. 2020, 530, 147254. [CrossRef]

125. Liu, X.; Wang, S.; Liang, Y.; Zhao, Y.; Yuan, N.; Sui, Z.; Chen, Q. Adenine-bearing covalent organic frameworks via one-pot tandem reaction for selective adsorption of $\mathrm{Ag}^{+}$. Microporous Mesoporous Mater. 2021, 315, 110923. [CrossRef]

126. Bagheri, A.R.; Ghaedi, M. Green preparation of dual-template chitosan-based magnetic water-compatible molecularly imprinted biopolymer. Carbohydr. Polym. 2020, 236, 116102. [CrossRef] [PubMed]

127. Guan, X.; Chen, F.; Fang, Q.; Qiu, S. Design and applications of three dimensional covalent organic frameworks. Chem. Soc. Rev. 2020, 49, 1357-1384. [CrossRef] [PubMed]

128. Peng, Y.; Wang, B.; Mao, Y. Study on force schemes in pseudopotential lattice Boltzmann model for two-phase flows. Math. Probl. Eng. 2018, 1-9. [CrossRef]

129. Fan, H.; Mundstock, A.; Feldhoff, A.; Knebel, A.; Gu, J.; Meng, H.; Caro, J. Covalent organic framework-covalent organic framework bilayer membranes for highly selective gas separation. J. Am. Chem. Soc. 2018, 140, 10094-10098. [CrossRef]

130. Yang, X.; Wang, J.; Yang, Q.; Pei, H.; Hu, N.; Suo, Y.; Li, Z.; Zhang, D.; Wang, J. Facile fabrication of robust MOF membranes on cloth via a CMC macromolecule bridge for highly efficient $\mathrm{Pb}$ (II) removal. Chem. Eng. J. 2018, 339, 230-239. [CrossRef]

131. Abdollahi, N.; Razavi, S.A.A.; Morsali, A.; Hu, M.-L. High capacity Hg(II) and $\mathrm{Pb}(\mathrm{II})$ removal using MOF-based nanocomposite: Cooperative effects of pore functionalization and surface-charge modulation. J. Hazard. Mater. 2020, 387, 121667. [CrossRef] [PubMed]

132. Huang, Y.; Zeng, X.; Guo, L.; Lan, J.; Zhang, L.; Cao, D. Heavy metal ion removal of wastewater by zeolite-imidazolate frameworks. Sep. Purif. Technol. 2018, 194, 462-469. [CrossRef]

133. Madadrang, C.J.; Kim, H.Y.; Gao, G.; Wang, N.; Zhu, J.; Feng, H.; Gorring, M.; Kasner, M.L.; Hou, S. Adsorption Behavior of EDTA-Graphene Oxide for Pb (II) Removal. ACS Appl. Mater. Interfaces 2012, 4, 1186. [CrossRef] [PubMed]

134. Rakhym, A.B.; Seilkhanova, G.A.; Kurmanbayeva, T.S. Adsorption of lead (II) ions from water solutions with natural zeolite and chamotte clay. Mater. Today Proc. 2020, 31, 482-485. [CrossRef]

135. Mudasir, M.; Karelius, K.; Aprilita, N.H.; Wahyuni, E.T. Adsorption of mercury (II) on dithizone-immobilized natural zeolite. J. Environ. Chem. Eng. 2016, 4, 1839-1849. [CrossRef]

136. Rasheed, T.; Hassan, A.A.; Bilal, M.; Hussain, T.; Rizwan, K. Metal-organic frameworks based adsorbents: A review from removal perspective of various environmental contaminants from wastewater. Chemosphere 2020, 259, 127369. [CrossRef]

137. Forghani, M.; Azizi, A.; Livani, M.J.; Kafshgari, L.A. Adsorption of lead (II) and chromium (VI) from aqueous environment onto metal-organic framework MIL-100(Fe): Synthesis, kinetics, equilibrium and thermodynamics. J. Solid State Chem. 2020, 291, 121636. [CrossRef]

138. Limei, C.; Xiaoyao, G.; Qin, W.; Yaoguang, W.; Liang, G.; Liangguo, Y.; Tao, Y.; Bin, D. Removal of mercury and methylene blue from aqueous solution by xanthate functionalized magnetic graphene oxide: Sorption kinetic and uptake mechanism. J. Colloid. Interface Sci. 2015, 439, 112-120. [CrossRef]

139. Bourlinos, A.B.; Dallas, P.; Sanakis, Y.; Stamopoulos, D.; Trapalis, C.; Niarchos, D. Synthesis and characterization of a $\pi$-conjugate, covalent layered network derived from condensation polymerization of the 4,4'-bipyridine-cyanuric chloride couple. Eur. Polym. J. 2006, 42, 2940-2948. [CrossRef]

140. Zhao, W.; Xia, L.; Liu, X. Covalent organic frameworks (COFs): Perspectives of industrialization. CrystEngComm $2018,20,1613$. [CrossRef] 
141. Karak, S.; Kandambeth, S.; Biswal, B.P.; Sasmal, H.S.; Kumar, S.; Pachfule, P.; Banerjee, R. Constructing ultraporous covalent organic frameworks in seconds via an organic terracotta process. J. Am. Chem. Soc. 2017, 139, 1856-1862. [CrossRef] [PubMed]

142. Huang, W.; Jiang, Y.; Li, X.; Li, X.; Wang, J.; Wu, Q.; Liu, X. Solvothermal synthesis of microporous, crystalline covalent organic framework nanofibers and their colorimetric nanohybrid structures. ACS Appl. Mater. Interfaces 2013, 5, 8845-8849. [CrossRef]

143. Das, G.; Shinde, D.B.; Kandambeth, S.; Biswal, B.P.; Banerjee, R. Mechanosynthesis of imine, $\beta$-ketoenamine, and hydrogenbonded imine-linked covalent organic frameworks using liquid-assisted grinding. Chem. Commun. 2014, 50, 12615-12618. [CrossRef] [PubMed]

144. Ma, X.; Scott, T.F. Approaches and challenges in the synthesis of three-dimensional covalent-organic framework. Commun. Chem. 2018, 98, 1-5. [CrossRef]

145. Sajid, M.I. Toxicity of Nanoscale Metal-Organic Frameworks in Biological Systems. In Metal-Organic Frameworks for Biomedical Applications; Elsevier: Amsterdam, The Netherlands, 2020; pp. 383-395. [CrossRef]

146. Sajid, M.; Ilyas, M.; Basheer, C.; Tariq, M.; Daud, M.; Baig, N.; Shehzad, F. Impact of nanoparticles on human and environment: Review of toxicity factors, exposures, control strategies, and future prospects. Environ. Sci. Pollut. Res. 2015, 22, 4122-4143. [CrossRef]

147. Bhunia, S.; Deo, K.A.; Gaharwar, A.K. 2D Covalent Organic Frameworks for Biomedical Applications. Adv. Funct. Mater. 2020, 30, 1-27. [CrossRef]

148. Chen, H.; Lin, T.; Zhang, S.; Chen, W.; Xu, H.; Tao, H. Covalent organic frameworks as an efficient adsorbent for controlling the formation of disinfection by-products (DBPs) in chlorinated drinking water. Sci. Total Environ. 2020, 746, 141138. [CrossRef]

149. Xia, Z.; Zhao, Y.; Darling, S.B. Covalent Organic Frameworks for Water Treatment. Adv. Mater. Interfaces 2021, 8, 1-17. [CrossRef]

150. Yuan, S.; Li, X.; Zhu, J.; Zhang, G.; van Puyvelde, P.; van der Bruggen, B. Covalent organic frameworks for membrane separation. Chem. Soc. Rev. 2019, 48, 2665-2681. [CrossRef]

151. Salonen, L.M.; Pinela, S.R.; Fernandes, S.P.; Louçano, J.; Carbó-Argibay, E.; Sarriá, M.P.; Rodríguez-Abreu, C.; Peixoto, J.; Espiña, B. Adsorption of marine phycotoxin okadaic acid on a covalent organic framework. J. Chromatogr. A 2017, 1525, 17-22. [CrossRef]

152. Li, Y.; Dong, G.; Li, J.; Xiang, J.; Yuan, J.; Wang, H.; Wang, X. Ecotoxicology and Environmental Safety A solid-phase microextraction fiber coating based on magnetic covalent organic framework for highly efficient extraction of triclosan and methyltriclosan in environmental water and human urine samples. Ecotoxicol. Environ. Saf. 2021, 219, 112319. [CrossRef]

153. Fernandes, S.P.; Mellah, A.; Kovář, P.; Sárria, M.P.; Pšenička, M.; Djamila, H.; Salonen, L.M.; Espiña, B. Extraction of ibuprofen from natural waters using a covalent organic framework. Molecules 2020, 25, 3132. [CrossRef]

154. Kou, X.; Tong, L.; Huang, S.; Chen, G.; Zhu, F.; Ouyang, G. Recent advances of covalent organic frameworks and their application in sample preparation of biological analysis. Trac. Trends Anal. Chem. 2021, 136, 116182. [CrossRef]

155. Das, G.; Benyettou, F.; Sharama, S.K.; Prakasam, T.; Gandara, F.; de la Pena-O'Shea, V.; Saleh, N.; Pasricha, R.; Jagannathan, R.; Olson, M.A.; et al. Covalent organic nanosheets for bioimaging. Chem. Sci. 2018, 9, 8382-8387. [CrossRef]

156. Mokhtari, N.; Taymouri, S.; Mirian, M.; Dinari, M. Covalent triazine-based polyimine framework as a biocompatible pHdependent sustained-release nanocarrier for sorafenib: An in vitro approach. J. Mol. Liq. 2020, 297, 111898. [CrossRef]

157. Rengaraj, A.; Puthiaraj, P.; Haldorai, Y.; Heo, N.; Hwang, S.K.; Han, Y.K.; Kwon, S.; Ahn, W.S.; Huh, Y.S. Porous covalent triazine polymer as a potential nanocargo for cancer therapy and imaging. ACS Appl. Mater. Interfaces 2016, 8, 8947-8955. [CrossRef] [PubMed]

158. Mi, Z.; Yang, P.; Wang, R.; Unruangsri, J.; Yang, W.; Wang, C.; Guo, J. Stable radical cation-containing covalent organic frameworks exhibiting remarkable structure-enhanced photothermal conversion. J. Am. Chem. Soc. 2019, 141, 14433-14442. [CrossRef] [PubMed] 